\title{
Biosorption of Fluoride from Aqueous Solution Using Lichen and Its Ca-Pretreated Biomass
}

\author{
Naba Kumar Mondal $^{1} \cdot$ Monalisa Kundu $^{1}$
}

Received: 29 April 2016 / Revised: 29 June 2016 / Accepted: 24 July 2016 / Published online: 6 August 2016

(C) Springer Science+Business Media Singapore 2016

\begin{abstract}
One of the major ground water contaminants is fluoride; hence, numerous procedures for its removal are reported. In this study, adsorption of fluoride was investigated by lichen and its Ca-pretreated lichen biomass from aqueous solution. The entire study was done by batch adsorption mode. The operating parameters such as $\mathrm{pH}$, adsorbent dose, stirring rate, contact time, particle size, initial fluoride solution, and temperature in such solution influence the degree of fluoride ions adsorption. The kinetics of the fluoride adsorption was calculated by pseudo-first order and pseudosecond order and intraparticle diffusion rate laws. The surface morphology was evaluated by scanning electron micrograph (SEM). In this biosorption study, results revealed that Ca-pretreated lichen showed higher removal at $\mathrm{pH}$ 6. The fluoride adsorption isotherms, D-R and Langmuir isotherms are well fitted for both the biomasses and pseudo-secondorder kinetic model showed high regression coefficient. The Langmuir adsorption capacity of lichen and Ca-pretreated lichen are $0.81 \mathrm{mg} / \mathrm{g}$ and $1.72 \mathrm{mg} / \mathrm{g}$, respectively. The FTIR study showed active functional groups associated with biomass. Thermodynamic parameters such as Gibbs free energy $\left(\Delta \mathrm{G}^{\circ}\right)$, enthalpy $\left(\Delta \mathrm{H}^{\circ}\right)$, and entropy $\left(\Delta \mathrm{S}^{\circ}\right)$ change of sorption were also evaluated which indicated that the adsorption process was spontaneous, feasible, and exothermic in nature. The present findings suggest that lichen biomass may be used as an inexpensive and effective adsorbent.
\end{abstract}

Naba Kumar Mondal

nkmenvbu@gmail.com

1 Environmental Chemistry Laboratory, Department of Environmental Science, The University of Burdwan, Burdwan, West Bengal, India
Keywords Lichen · Ca-pretreated · Fluoride · Adsorption · Adsorption isotherm $\cdot$ Kinetics and thermodynamic

\section{Introduction}

Fluorine is an extremely reactive and highly toxic gaseous element. The main natural source of inorganic fluorides in soil is the parent rock [1]. The fluoride occurs notably as Sellaite, fluorspar, $\mathrm{CaF}_{2}$; Cryolite, $\mathrm{Na}_{3} \mathrm{AlF}_{6}$; Fluorapatite, $3 \mathrm{Ca}_{3}(\mathrm{PO} 4)_{2} \mathrm{Ca}\left(\mathrm{F}, \mathrm{Cl}_{2}\right)$, etc. Fluorides are released into the environment naturally through the weathering of minerals, in emissions from volcanoes, and in marine aerosols [2]. The industrial effluent and sewage discharge also contribute to increase the fluoride levels in aquatic systems [3]. In drinking water, high fluoride level has become a critical health hazard of this century as it induces intense impact on human health including skeletal and dental fluorosis [4]. The guideline value established by the World Health Organization (WHO) is $1.5 \mathrm{mg} / \mathrm{L}$, but this is not a fixed value which will be intended to be adapted to take account of local conditions [5].

Defluoridation of drinking water is the only practicable way to overcome the problem of excessive fluoride in drinking water. Traditional treatment method such as adsorption, ion exchange, precipitation, electro-dialysis, and reverse osmosis has been employed for fluoride removal from water [6-8]. Moreover, other methods, such as filtration, ultrafiltration, microfiltration, and active carbon are developed for efficient adsorption process, which are quite expensive [9, 10]. A large number of materials have been tested, such as activated silica gel, rice husk [11], tea ash [12], activated carbon [13], calcite [14], calcareous soil [15], aluminum-impregnated potato plant ash [16], Fe-Al-impregnated granular ceramic [4], and calcium-impregnated coconut fiber [17] for the removal 
Table 1 Mathematical equations of different isotherm models

\begin{tabular}{|c|c|c|c|}
\hline $\begin{array}{l}\text { Isotherm } \\
\text { models }\end{array}$ & $\begin{array}{l}\text { Mathematical } \\
\text { equations }\end{array}$ & Plots & References \\
\hline Langmuir & $\frac{1}{q_{e}}=\frac{1}{q_{\max } K_{L} C_{e}}+\frac{1}{q_{\max }}$ & $\frac{1}{q_{e}}$ vs. $\frac{1}{C_{e}}$ & {$[22]$} \\
\hline Freundlich & $\log q_{e q}=\log K_{F}+\frac{1}{n} \log C_{e}$ & $\begin{array}{l}\log q_{e q} \mathrm{Vs} \\
\quad \log C_{e}\end{array}$ & {$[23]$} \\
\hline $\begin{array}{l}\text { Dubinin- } \\
\text { Radushkevich } \\
\text { (D-R) }\end{array}$ & $\ln q_{e}=\ln q_{m}-\beta \varepsilon^{2}$ & $\ln q_{e} \mathrm{VS} . \varepsilon^{2}$ & {$[22]$} \\
\hline Tempkin & $q_{e}=B \ln A+B \ln C_{e}$ & $\begin{array}{l}q_{e} \mathrm{vs} \\
\quad \ln C_{e}\end{array}$ & {$[20]$} \\
\hline
\end{tabular}

of fluoride. A lichen is a composite organism that arises from algae or cyanobacteria (or both) living among filaments of a fungus in a symbiotic relationship. Lichens occur from sea level to high alpine elevations, in a very wide range of environmental conditions, and can grow on almost any surface. Lichens are abundant growing on bark, leaves, mosses, on other lichens, and hanging from branches "living on thin air" (epiphytes) in rain forests and in temperate woodland. It is estimated that $6 \%$ of Earth's land surface is covered by lichen.

In the present study, an attempt has been made to develop an inexpensive natural adsorbent system for the removal of fluoride from aqueous solution using lichen biomass. Being negatively charged, surface lichen cannot absorb sufficient anions. However, fluoride can be removed by using a technique to pretreated surface with $\mathrm{Ca}^{2+}[18]$. In view of this, in the proposed study, Lichen biomass were used to pretreated with cations and find if fluoride removal may be affected using this technique. This is the comparative study between lichen and Ca-pretreated lichen to find out the best removal efficiency of fluoride. The whole experiments were conducted in batch mode. Several factors affecting the removal process have been studied. The application of adsorption isotherms and the kinetics study determined controlling factors in the adsorption process and finally thermodynamics study, FTIR and SEM study have also been conducted.

Table 2 Mathematical equations of different kinetics models

\begin{tabular}{llll}
\hline Kinetics model & Mathematical equations & Plots & References \\
\hline $\begin{array}{l}\text { Pseudo-first } \\
\text { order }\end{array}$ & $\begin{array}{c}\log \left(q_{e}-q_{t}\right)=\log q_{e}-K_{1} \\
\frac{t}{2.303}\end{array}$ & $\begin{array}{c}\log \left(q_{e}-\right. \\
\left.q_{t}\right) \text { vs. } \mathrm{t}\end{array}$ & \\
$\begin{array}{l}\text { Pseudo-second } \\
\text { order }\end{array}$ & $\frac{t}{q_{t}}=\frac{1}{K_{2} q_{e}{ }^{2}}+\frac{t}{q_{e}}$ & $\frac{t}{q_{t}}$ vs. $t$ & {$[25]$} \\
$\begin{array}{l}\text { Intraparticle } \\
\text { diffusion }\end{array}$ & $q_{t}=K_{i} t^{0.5}+I$ & $q_{t}$ vs. $t^{0.5}$ & {$[26]$} \\
\hline
\end{tabular}

\section{Materials and Methods}

\section{Adsorbent Preparation}

\section{Nature of Lichen}

A lichen is a composite organism that arises from algae or cyanobacteria (or both) living among filaments of a fungus in a symbiotic relationship. The combined life form has properties that are very different from the properties of its component organisms. The studied lichen is crustose type microlichen. Crustose lichens form a crust that strongly adheres to the substrate (soil, rock, tree bark, etc.), making separation from the substrate impossible without destruction. The basic structure of crustose lichens consists of a cortex layer, an algal layer, and a medulla. The upper cortex layer is differentiated and is usually pigmented. The algal layer lies beneath the cortex. The medulla fastens the lichen to the substrate and is made up of fungal hyphae. The surface of crustose lichens is characterized by branching cracks that periodically close in response to climatic variations such as alternate wetting and drying regimes. The scientific classification of the lichen are Kingdom: Fungi; Division: Ascomycota; Class: Leca noromycetes; Order: Lecanorales.

\section{Preparation of Lichen Biomass}

Lichen (microlichen) was collected from the Golapbag campus of the University of Burdwan (23d15'20.10" N; $87 \mathrm{~d} 50$ '50.70" E). Then the sample was washed with distilled water after collection from the bark of tree and allowed to dry within the incubator at $37{ }^{\circ} \mathrm{C}$ for $24 \mathrm{~h}$. The dried biomass was finally grinded by using mixer grinder and sieved through three different standard sieves to obtain particle size of 50, 100, and $150 \mu \mathrm{m}$. The powdered form of biomass is stored into three different sterile containers and kept into desiccators for further experiment.

\section{Preparation of Ca-Pretreated Lichen Biomass}

A $0.5 \mathrm{~g}$ of dried biomass was suspended in a beaker containing $100 \mathrm{~mL}$ of aqueous $\mathrm{CaCl}_{2}$ solution in the concentration of $100 \mathrm{mg} / \mathrm{L}$ and mixed well for $30 \mathrm{~min}$ on a stirring machine. After that, Ca-pretreated biomass was collected by filtration with Whatman-42 filter paper and allowed to dry in room temperature [19]. The dried biomass was finally grinded by using mixer grinder and sieved through three different standard sieves to obtain particle size of 50,100 , and $150 \mu \mathrm{m}$. Finally, the dried biomass stored into the air-tight container and kept into desiccators for further experiment. 
Table 3 Physicochemical characteristics of lichen and Capretreated lichen

\begin{tabular}{lrccl}
\hline Parameters & \multicolumn{1}{l}{ Lichen } & Ca-pretreated lichen & “ $t$ value & Significant level \\
\hline $\mathrm{pH}$ & $6.65 \pm 0.044$ & $6.7 \pm 0.078$ & 2.50 & 0.130 \\
Cond. & $10 \pm 0.436$ & $12 \pm 0.361$ & 10.00 & 0.01 \\
Specific gravity & $0.285 \pm 0.066$ & $0.297 \pm 0.004$ & 1.97 & 0.187 \\
Bulk density $\left(\mathrm{g} / \mathrm{cm}^{3}\right)$ & $0.255 \pm 0.007$ & $0.243 \pm 0.009$ & 4.00 & 0.057 \\
Particle density $\left(\mathrm{g} / \mathrm{cm}^{3}\right)$ & $0.723 \pm 0.006$ & $0.687 \pm 0.015$ & 2.96 & 0.098 \\
Porosity $(\%)$ & $64.73 \pm 0.321$ & $64.62 \pm 0.923$ & 0.25 & 0.829 \\
Moisture $(\%)$ & $2.76 \pm 0.087$ & $2.84 \pm 0.066$ & 0.94 & 0.448 \\
$\mathrm{pH}$ & $6.6 \pm 0.100$ & $6.5 \pm 0.100$ & 1.00 & 0.423 \\
\hline
\end{tabular}

\section{Preparation of Test Solution}

A 100 ppm of stock solution was prepared by dissolving $0.221 \mathrm{~g} \mathrm{NaF}$ with distilled water. The entire experimental reagent is AR grade. Intermediate solution was prepared from
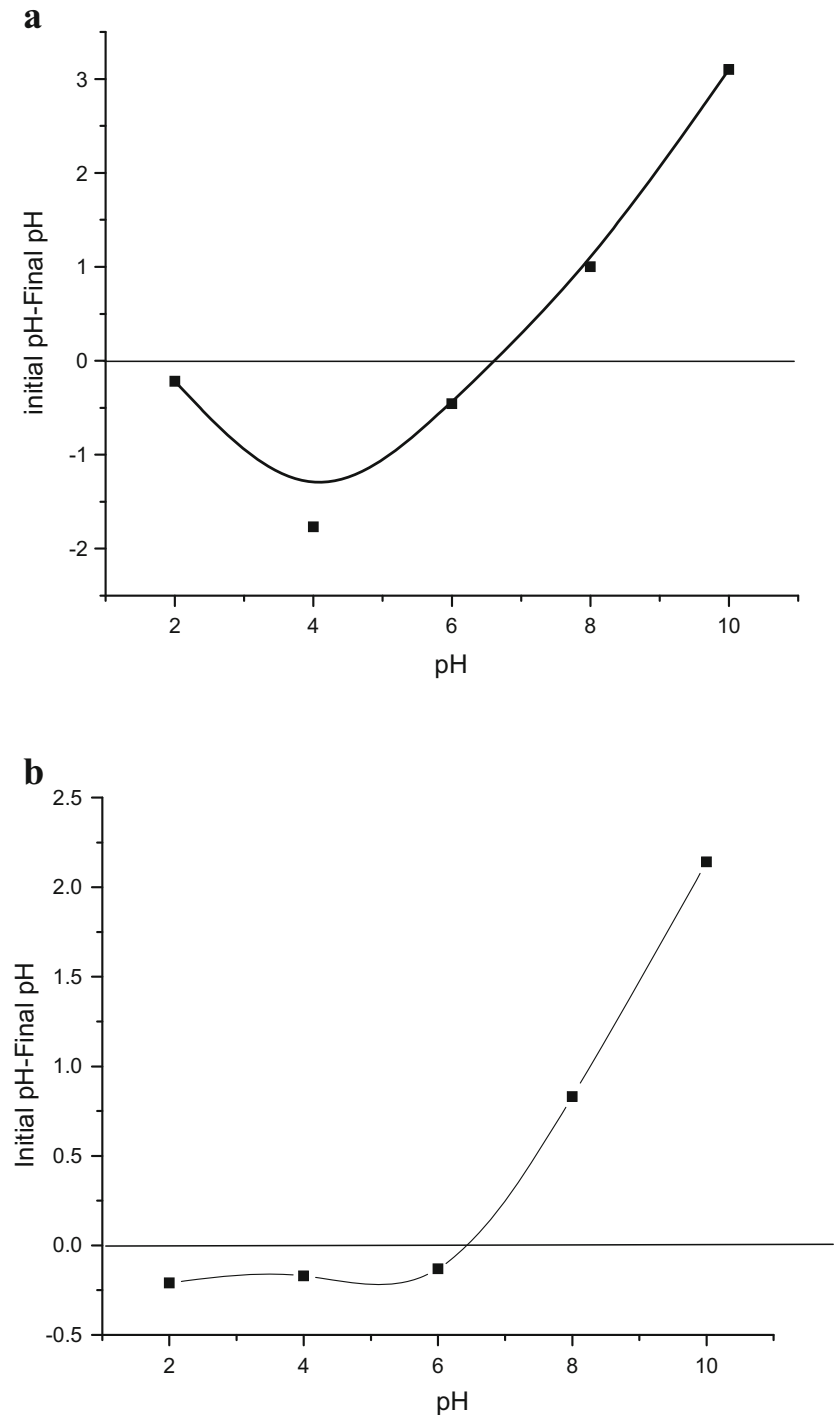

Fig. 1 a $\mathrm{pH}_{\mathrm{zpc}}$ of lichen. $\mathbf{b} \mathrm{pH}_{\mathrm{zpc}}$ of Ca-pretreated lichen stock solution (100 ppm) through appropriate dilution by using double distilled water.

\section{Instruments and Apparatus}

The scanning electron microscopy (SEM) is helpful to understand the surface morphology of the adsorbent. In this study, images were recorded by using SEM analyzer (HITACHI, S-530, Scanning Electron Microscope and ELKO Engineering) at an accelerating voltage of $20.0 \mathrm{kV}$. Automated Mercury Porosimeters (Quantachrome, model Pore Master 60 GT) were used to determine the pore size distribution, since this method is suitable for determining larger pores such as mesopores or micropores. The Fourier transform infrared (FTIR) study was carried out to record the potential functional groups involved in the adsorption process by means of FTIR (BRUKER, Tensor 27). The $\mathrm{pH}$ values of the solutions at the beginning and the end of the experiments were measured using Systronic 6.3 digital $\mathrm{pH}$ meter, and the average values were taken. Temperature-controlled magnetic stirrer (Tarsons, Spinot digital model MC02, CAT No. 6040, S. No. 173) was used during the adsorption experiments. Ion-selective electrode (ORION, 4 Star) has been used to measure fluoride concentration.

\section{Zero Point Charge $\left(\mathrm{pH}_{\mathrm{ZPC}}\right)$}

$\mathrm{pH}_{\mathrm{ZPC}}$ of the lichen and Ca-pretreated lichen was determined by the solid addition method [20]. Two separate sets (one set for lichen and another for Ca-pretreated lichen) of $50 \mathrm{~mL}$ of $0.1 \mathrm{M} \mathrm{KNO}_{3}$ solution were transferred into a series of $100 \mathrm{~mL}$ conical flasks. The $\mathrm{pH}$ of the $\mathrm{KNO}_{3}$ solution was adjusted by using $0.05(\mathrm{~N}) \mathrm{HNO}_{3}$ and $0.1 \mathrm{~N} \mathrm{KOH}$ solutions. After following the standard method [20], $\mathrm{pH}$ of the final solutions was measured. The change in the $\mathrm{pH}$ affects the adsorptive process through dissociation of functional groups as the active sites on the surface of the adsorbent [21]. This subsequently leads to a shift in the reaction kinetics and the equilibrium characteristics of the adsorption process [20]. 

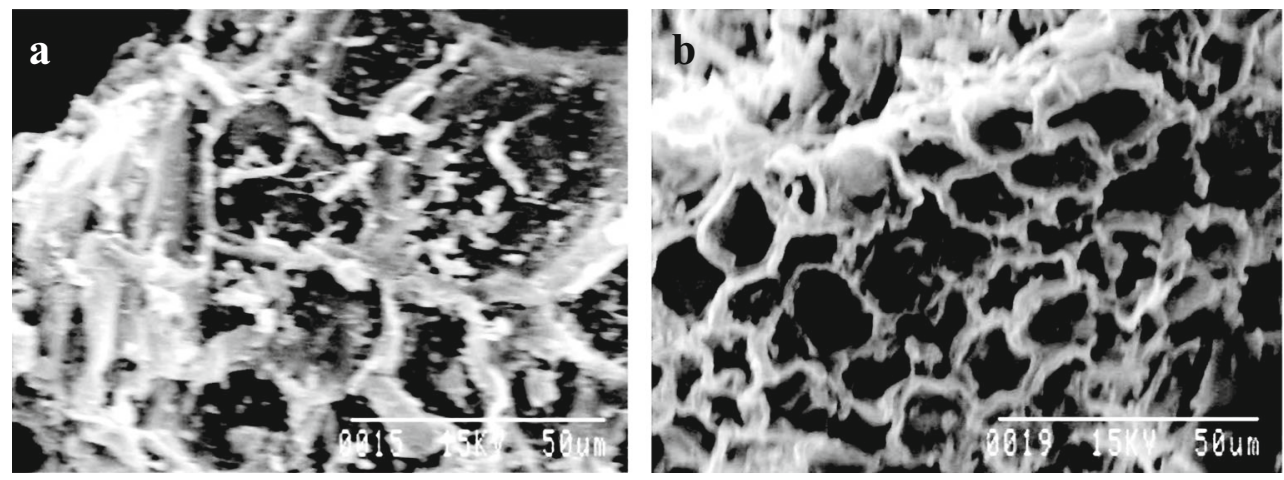

Fig. 2 a Scanning electron microscopy of lichen before passing fluoride solution. ( $\times 1000$ magnification $)$. b Scanning electron microscopy of lichen after fluoride loading $(\times 1000$ magnification $)$

\section{Batch Adsorption Studies}

The batch experiments were carried out in $250 \mathrm{~mL}$ conical flask with $100 \mathrm{~mL}$ of working volume, with a concentration of $50 \mathrm{mg} / \mathrm{L}$. A weighted amount of adsorbent $(0.1 \mathrm{~g})$ was added to the solution. The flask was agitated at a constant speed at $250 \mathrm{rpm}$ for $1 \mathrm{~h}$ in a stirring machine (Tarsons, Spinot digital model MCO2, CAT no. $6040, \mathrm{~S}$ no. 173) at $313 \pm 1 \mathrm{~K}$. The influence of $\mathrm{pH}$ range from 2 to 10 , adsorbent dose 0.1 to $1.0 \mathrm{~g}$, stirring rate 150 to $350 \mathrm{rpm}$, contact time 20 to $120 \mathrm{~min}$, particle size 50 to $150 \mu$, initial fluoride concentration 1.5 to $35 \mathrm{ppm}$, and finally changes of temperature ranges from 313 to $373 \mathrm{~K}$ were evaluated in the present study. The amount of fluoride adsorbed per unit adsorbent ( $\mathrm{mg}$ fluoride per $\mathrm{g}$ adsorbent) was calculated according to a mass balance Eq. (1):

$q_{e}=\frac{\left(C_{i}-C_{e}\right) V}{m}$

where $C_{i}$ is the initial fluoride concentration $\left(\mathrm{mg} \mathrm{L}^{-1}\right), C_{e}$ is the equilibrium fluoride concentration in solution $\left(\mathrm{mg} \mathrm{L}^{-1}\right), V$ is the volume of the solution (L), and $m$ is the mass of the adsorbent in grams. The percent removal (\%) of fluoride was calculated using the following Eq. (2):

$\operatorname{Removal}(\%)=\frac{C_{i}-C_{e}}{C_{i}} \times 100$

All adsorption experiments were performed in triplicate, and the mean values were used in data analysis. Control experiments, performed without the addition of adsorbent, confirmed that the sorption of fluoride on the walls of Erlenmeyer flasks was negligible.

\section{Adsorption Isotherms}

The analysis of data by adsorption isotherms is very important to design of an adsorbent and for calculating the adsorption efficiency of the adsorbent systems. In this study, Langmuir, Freundlich, D-R and Tempkin adsorption isotherm models are analyzed and mathematical expressions of these models are given in Table 1.

\section{Adsorption Kinetics}

The rate of fluoride adsorption on fluoride was determined by studying the adsorption kinetics at fixed initial
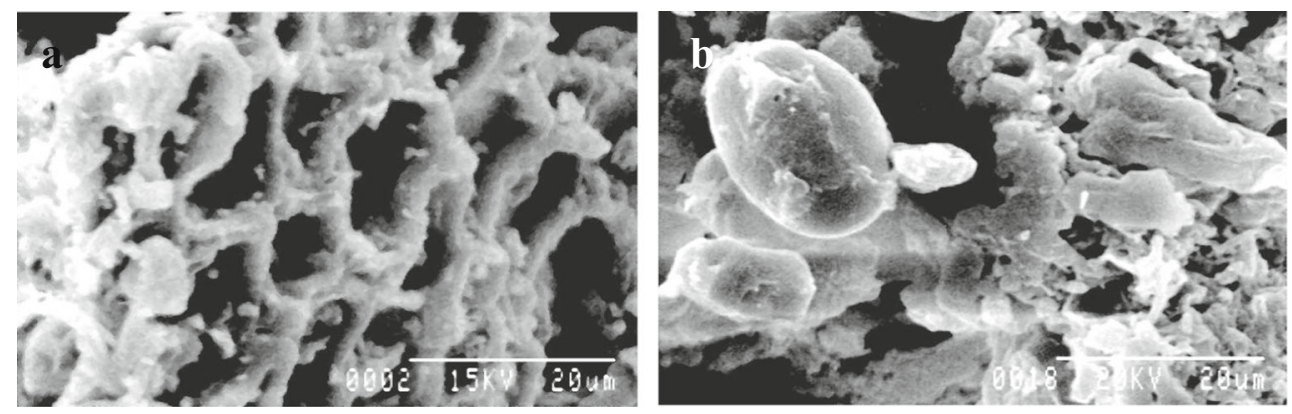

Fig. 3 a Scanning electron microscopy of Ca-pretreated lichen before passing fluoride solution $(\times 2000$ magnification $)$. b Scanning electron microscopy of Ca-pretreated lichen after fluoride loading ( $\times 2000$ magnification) 

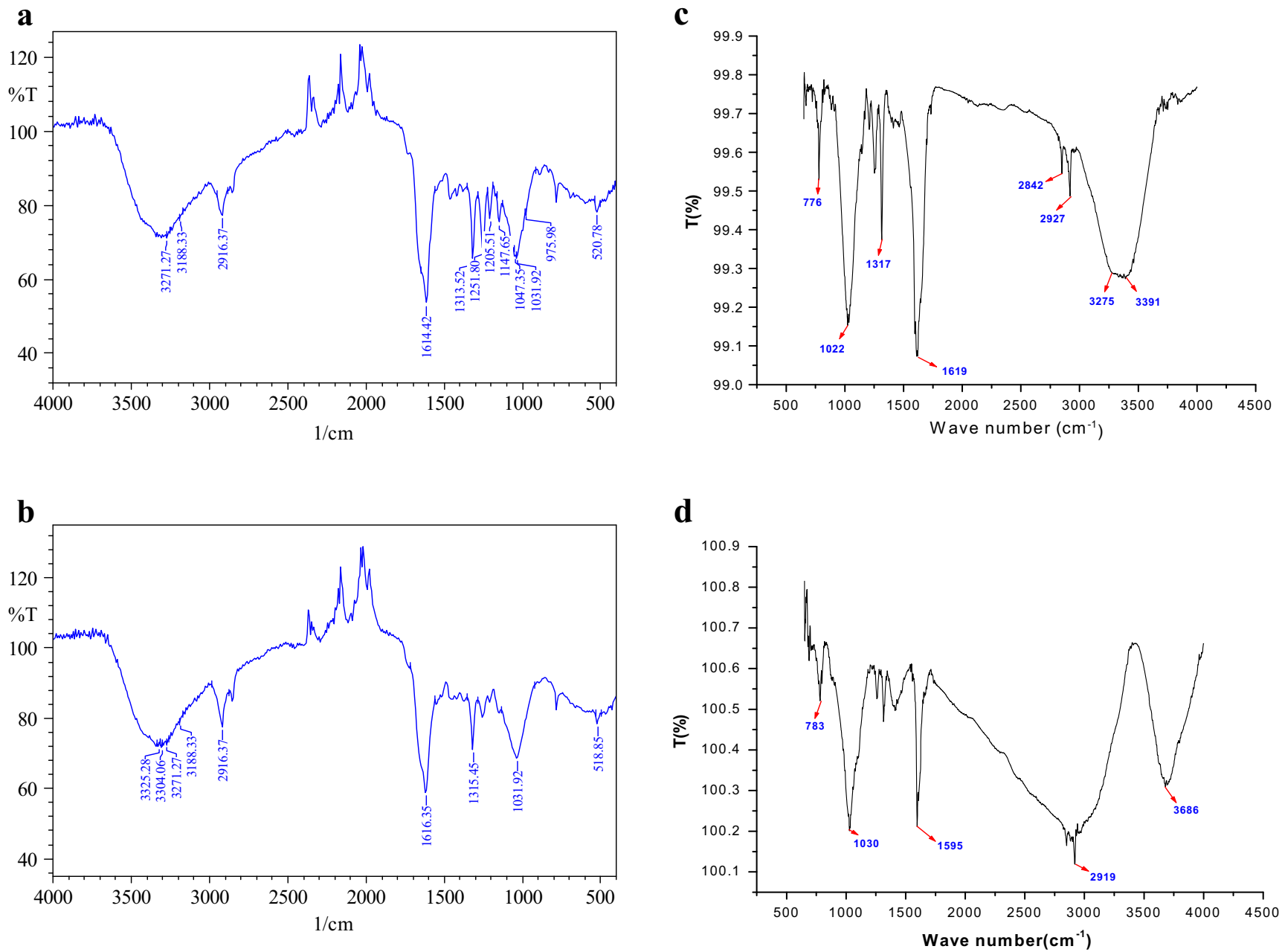

Fig. 4 a FTIR of lichen before adsorption of fluoride. b FTIR of lichen after adsorption of fluoride. $\mathbf{c}$ Calcium-impregnated lichen before fluoride loading. d Calcium impregnation lichen after fluoride loading

concentration with different time interval and fixed adsorbent dose. The kinetics of fluoride adsorption can be assessed by pseudo-first-order, pseudo-second-order kinetics, and intraparticle diffusion model and mathematical expressions of these models are given in Table 2.

\section{Activation Energy and Thermodynamic Parameters}

The activation energy $E_{a}$ for fluoride adsorption onto lichen was calculated by the Arrhenius Eq. (3):

$\ln K=\ln A-\frac{E_{a}}{R T}$

where $k$ is the rate constant, $A$ is the Arrhenius constant, $E_{a}$ is the activation energy $\left(\mathrm{kJ} \mathrm{mol}^{-1}\right), R$ is the gas constant $\left(8.314 \mathrm{Jmol}^{-1} \mathrm{~K}^{-1}\right)$, and $T$ is the temperature $(\mathrm{K}) . E_{a}$ can be determined from the slope of a plot of lnk versus $1 / \mathrm{T}$. Thermodynamic behavior of adsorption of fluoride on lichen was evaluated by the thermodynamic parameters-Gibbs free energy change $\left(\Delta G^{\circ}\right)$, enthalpy $\left(\Delta H^{\circ}\right)$, and entropy $\left(\Delta S^{\circ}\right)$. These parameters were calculated using the following equations (3-6):

$\Delta G^{o}=-R T \ln K_{c}$

$K_{c}=\frac{C_{a}}{C_{e}}$

$\Delta G^{o}=\Delta H^{o}-T \Delta S^{o}$

where $K_{C}$ is the distribution coefficient for adsorption, $C_{a}$ is the equilibrium fluoride concentration on the adsorbent $\left(\mathrm{mg} \mathrm{L}^{-1}\right)$, and $C_{e}$ is the equilibrium fluoride concentration in solution $\left(\mathrm{mg} \mathrm{L}^{-1}\right)$. A plot of $\Delta \mathrm{G}^{\circ}$ versus temperature, $T$ will be linear with the slope and intercept giving the values of $\Delta \mathrm{H}^{\circ}$ and $\Delta \mathrm{S}^{\circ}$. 

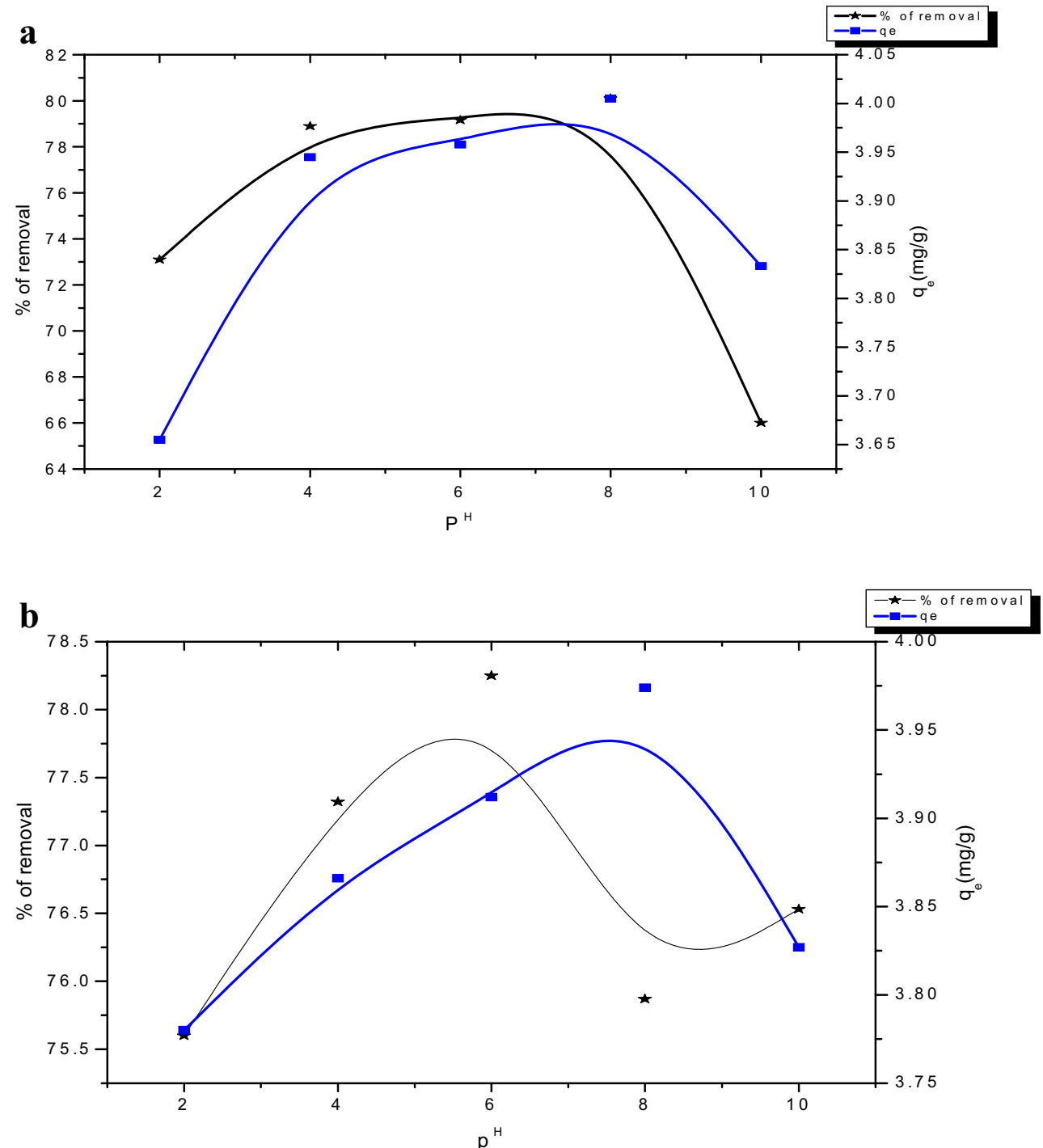

Fig. 5 a Effect of $\mathrm{pH}$ on removal of fluoride by lichen (initial fluoride concentration of $5.0 \mathrm{mg} / \mathrm{L}$; adsorbent dose of $0.1 \mathrm{~g} / 100 \mathrm{~mL}$; Contact time of $60 \mathrm{~min}$; stirring rate of $250 \mathrm{rpm}$; particle size of $100 \mu \mathrm{m}$; temperature of $313 \mathrm{~K})$. b Effect of $\mathrm{pH}$ on removal of fluoride by Ca-pretreated lichen

\section{Results and Discussion}

\section{Adsorbent Characterization}

The adsorbent characteristics of lichen and Ca-pretreated lichen are presented in Table 3. The adsorbents along with their Ca-pretreated mass are used for removal of fluoride. The study of surface characteristics of an adsorbent is an important property which makes it suitable for defluoridation.

\section{$\mathrm{pH}_{\mathrm{ZPC}}$ of Lichen and Ca-Pretreated Lichen}

The point of zero charge determines the linear range of $\mathrm{pH}$ sensitivity and then indicates the type of surface active centers and the adsorption ability of the surface [27]. The zero point (initial fluoride concentration of $5.0 \mathrm{mg} / \mathrm{L}$; adsorbent dose of $0.1 \mathrm{~g} /$ $100 \mathrm{~mL}$; contact time of $60 \mathrm{~min}$; stirring rate of $250 \mathrm{rpm}$; particle size of $150 \mu \mathrm{m}$; temperature of $313 \mathrm{~K}$ )

charge of lichen (Fig. 1a) and Ca-pretreated lichen (Fig. 1b) was measured by solid addition method [20]. The interaction between the surface component of the adsorbent and the fluoride is solely depends on the active functional groups present on the surface of the adsorbent [21]. Table 3 shows that the $\mathrm{pH}_{\mathrm{ZPC}}$ of lichen and Ca-pretreated lichen are 6.6 and 6.5, respectively.

\section{Scanning Electron Microscopy of Lichen}

The scanning electron micrograph studies (SEM) of lichen, before and after passing fluoride solution, are given at 1000 magnification in Fig. 2a, b. From the area of SEM study, it is clear that there is a huge porous, rough, irregular surface along with morphology of adsorbent before fluoride loading in 
Fig. 6 a Effect of adsorbent dose on removal of fluoride by using lichen (initial fluoride concentration of $5.0 \mathrm{mg} / \mathrm{L}$; $\mathrm{pH}$ of 8 ; contact time of $60 \mathrm{~min}$; stirring rate of $250 \mathrm{rpm}$; particle size of $100 \mu \mathrm{m}$; temperature of $313 \mathrm{~K})$. $\mathbf{b}$ Effect of adsorbent dose on removal of fluoride by $\mathrm{Ca}$ pretreated lichen (initial fluoride concentration of $5.0 \mathrm{mg} / \mathrm{L} ; \mathrm{pH}$ of 8 ; contact time of $60 \mathrm{~min}$; stirring rate of $250 \mathrm{rpm}$; particle size of $150 \mu \mathrm{m}$; temperature of $313 \mathrm{~K}$ )
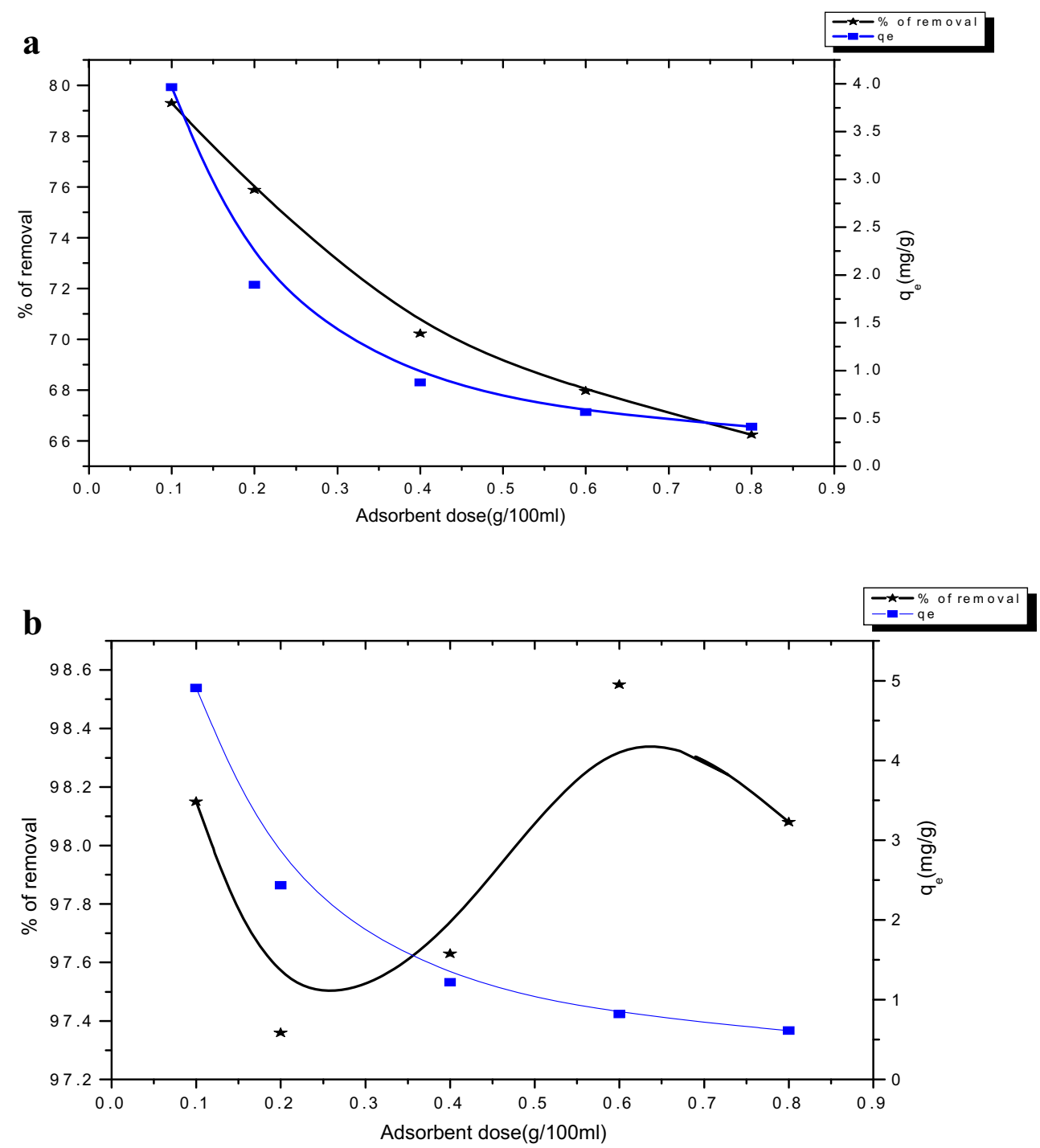

lichen, but Ca-pretreated lichen does not show such diffused area. Again, after fluoride adsorption, both lichen and $\mathrm{Ca}-$ pretreated lichen showed cloudy-like structure (Fig. 3a, b).

\section{FTIR Analysis}

FTIR spectroscopy was used to determine the participating functional groups of lichen and Ca-pretreated lichen biomass in fluoride biosorption (Figs. 4a and 5a). IR study clearly revealed that lichen has characteristics stretching frequency at $3271,3188,2916,1614,1313,1251 \mathrm{~cm}^{-1}$ and 975 which corresponds the functional groups such as $-\mathrm{OH},=\mathrm{C}-\mathrm{H}$, $-\mathrm{CHO},-\mathrm{C}=\mathrm{O}$, and $-\mathrm{CN}$, respectively, in raw lichen (Fig. 4a). However, after adsorption of fluoride, lichen surface functional groups grossly shifted to $3325,2916,1616,1315$, 1031 , and $518 \mathrm{~cm}^{-1}$ (Fig. 4b). On the other hand, Capretreated lichen showed distinct peaks at 3391, 2927, 2842, $1619,1317,1022$, and $776 \mathrm{~cm}^{-1}$ corresponds to the functional groups as $-\mathrm{OH},=\mathrm{C}-\mathrm{H}, \mathrm{C}-\mathrm{H},-\mathrm{C}=\mathrm{O}$ (carboxyl group), and -
$\mathrm{C}=\mathrm{C}-$, respectively (Fig. 4c). Similarly, after adsorption of fluoride onto Ca-pretreated lichen, the peaks such as 3331, $2842,1619,1022$, and $783 \mathrm{~cm}^{-1}$ slighted shifted to 3686 , 2919, 1595, 1030, and $783 \mathrm{~cm}^{-1}$ (Fig. 4c). Therefore, it is clear that majority of the surface functional groups actively involved in the fluoride adsorption process. However, in case of fluoride-loaded lichen, it showed almost unchanged IR (Fig. 4b). These results indicate the carboxyl $(-\mathrm{COOH})$ and hydroxyl $(-\mathrm{OH})$ groups of the biomass to be mainly involved in the biosorption of fluoride. The FTIR results obtained in the current study were similar to the data reported in the previous studies [28, 29].

\section{Effect of pH}

The $\mathrm{pH}$ of an aqueous solution is an important monitoring parameter in fluoride solution, as it affects the surface charged of the adsorbent material [30]. The $\mathrm{pH}_{\mathrm{zpc}}$ values of adsorbent also support the present findings. It influences the adsorption 
Fig. 7 a Effect of stirring rate on removal of fluoride by using lichen (initial fluoride concentration of $5.00 \mathrm{mg} / \mathrm{L} ; \mathrm{pH}$ of 8; adsorbent dose of $0.1 \mathrm{~g} /$ $100 \mathrm{~mL}$; Contact time of $60 \mathrm{~min}$; particle size of $100 \mu \mathrm{m}$; Temperature of $313 \mathrm{~K})$. b Effect of stirring rate on removal of fluoride by using Ca-pretreated lichen.(Initial fluoride concentration of $5.00 \mathrm{mg} / \mathrm{L}$; $\mathrm{pH}$ of 8; Adsorbent dose of $0.6 \mathrm{~g} /$ $100 \mathrm{~mL}$; Contact time of $60 \mathrm{~min}$; particle size of $150 \mu \mathrm{m}$; Temperature of $313 \mathrm{~K}$ )
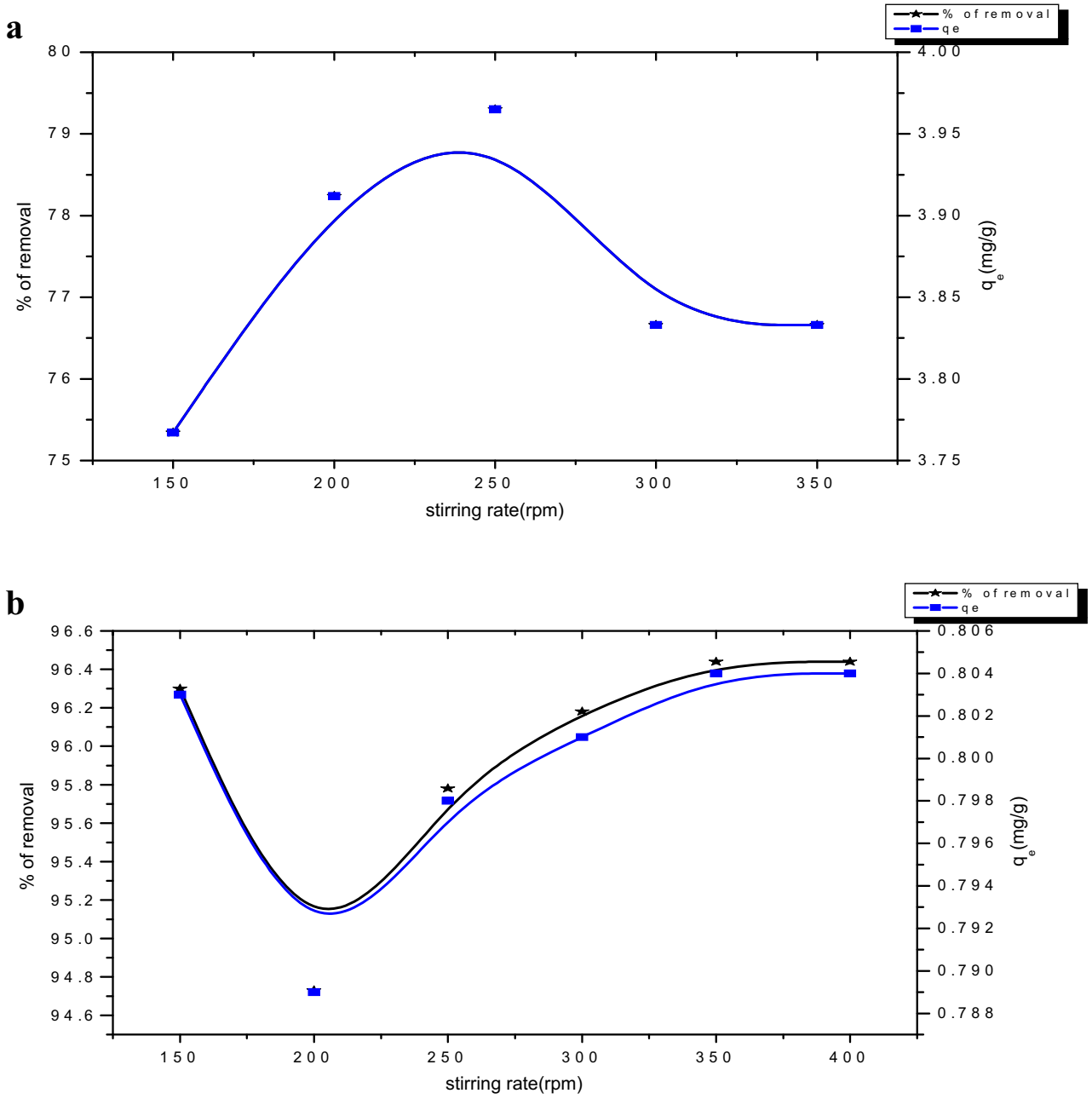

process by affecting the surface charge of adsorbent, the degree of ionization, and speciation of the adsorbate [31]. It is directly related with competition ability of $\mathrm{H}^{+}$ions with adsorbate ions to active sites on the adsorbent surface [32]. Thus, the effect of $\mathrm{pH}$ on the removal efficiency of fluoride was studied at different $\mathrm{pH}$ ranging from 2.0 to 10.0 (Fig. 4c). It was observed that maximum removal $(80.1 \%)$ of fluoride at pH 8 shows saturation in nature for lichen. But for Capretreated lichen, it shows maximum removal $(78.3 \%)$ at pH 6 (Fig. 4d). Present results are very consistent with our earlier report [19] where we showed that maximum $65.06 \%$ of fluoride was removed by Aspergillus at $\mathrm{pH} 10$ and $91.96 \%$ removal was recorded for Ca-pretreated Aspergillus at $\mathrm{pH} 8$. The maximum fluoride removal at $\mathrm{pH} 6$ is probably due to electrostatic attraction between calcium and fluoride $[4,33]$. Almost similar result was reported by Bhaumik and Mondal [21] for their earlier paper where they recorded that Ca-pretreated coconut fiber dust (CFD) can remove high level of fluoride at $\mathrm{pH}$ 6. They also suggested that fluoride ions are more attached to the surface of CFD-3 due to being chemically treated with $\mathrm{Ca}^{2+}$ solution (extracted from the eggshell) [34]. At higher $\mathrm{pH}$, the adsorption of fluoride is gradually decreased due to higher accumulation of hydroxyl ions on the surface of the adsorbent $[34,35]$.

\section{The Effect of Adsorbent Dose (g/100 mL)}

The amount of adsorbent (lichen) was taken in the range of $0.1 \mathrm{~g}$ to $0.8 \mathrm{~g} / 100 \mathrm{~mL}$. The maximum percentage of removal was recorded $79.3 \%$ at $0.1 \mathrm{~g} / 100 \mathrm{~mL}$ adsorbent dose (Fig. 6a). But reverse picture was recorded in case of Ca-pretreated lichen, and the percentage of fluoride removal increased with increasing the adsorbent dose. Such a trend is mostly attributed to an increase in their sorption surface area and availability of more active adsorption sites, and the maximum removal $(98.55 \%)$ was achieved at $0.6 \mathrm{~g} / 100 \mathrm{~mL}$ (Fig. 6b) [36]. The adsorbent dose for lichen does not show any linearity towards removal efficiency of fluoride. Probably the cell envelopes does not support the negative ion fluoride because it carry negative charges from their surface [37]. However, in case of Ca-pretreated lichen, fluoride removal strongly depends on adsorption dose. The changes in the extent of 
Fig. 8 a Effect of contact time on fluoride removal by using lichen (initial fluoride concentration of $5.0 \mathrm{mg} / \mathrm{L} ; \mathrm{pH}$ of 8 ; adsorbent dose of $0.1 \mathrm{~g} / 100 \mathrm{~mL}$; particle size of $100 \mu \mathrm{m}$; stirring rate of $250 \mathrm{rpm}$; temperature of $313 \mathrm{~K}$ ). b Effect of contact time on fluoride removal by using Ca-pretreated lichen (initial fluoride concentration of $5.0 \mathrm{mg} / \mathrm{L} ; \mathrm{pH}$ of 8 ; adsorbent dose of $0.6 \mathrm{~g} / 100 \mathrm{~mL}$; particle size of $150 \mu \mathrm{m}$; stirring rate of $350 \mathrm{rpm}$; temperature of $313 \mathrm{~K}$ )
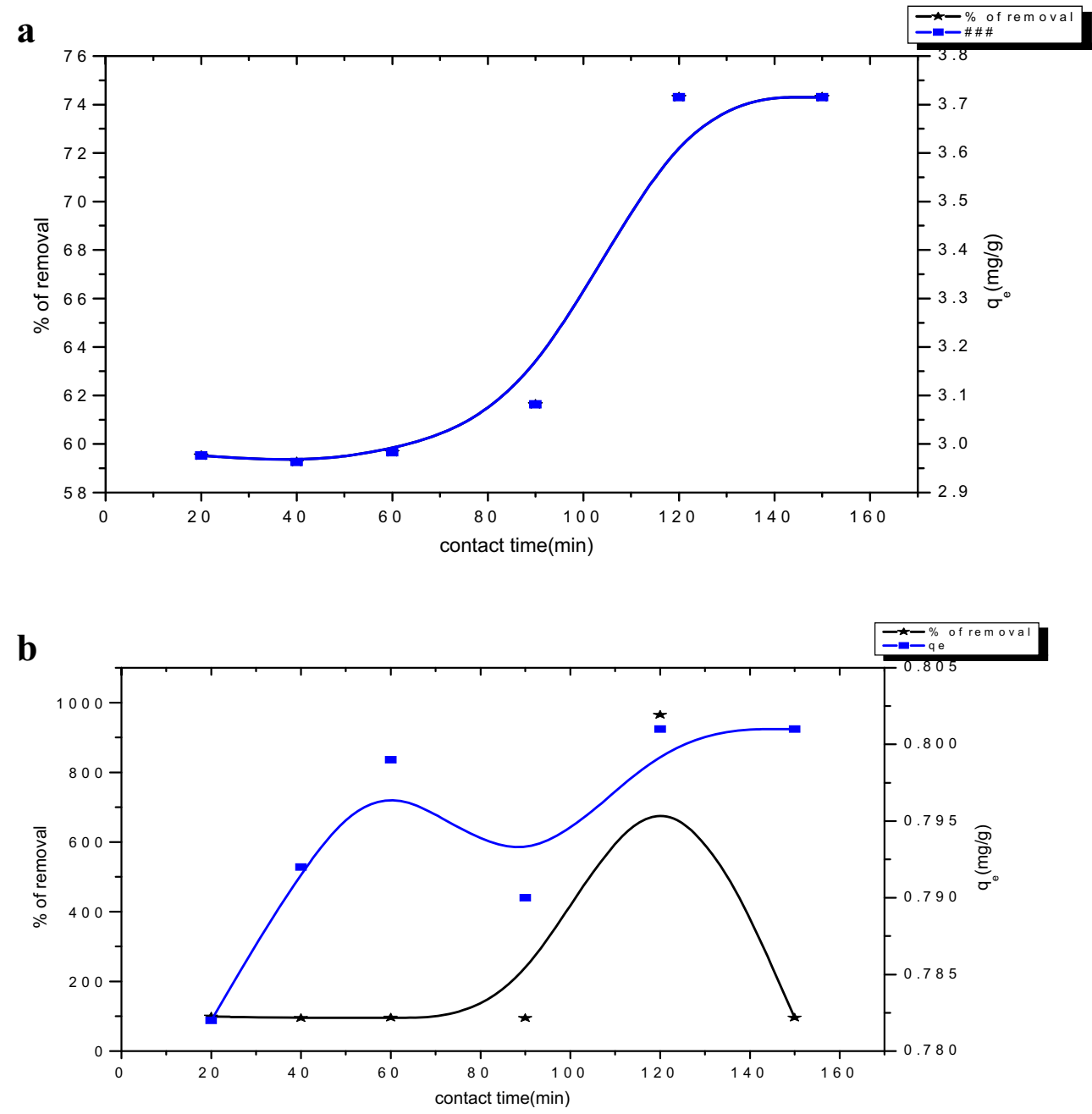

removal might be due to the fact that initially all adsorbent sites were vacant and the solid concentration gradient was high. Later, the fluoride uptake by adsorbent decreases with the number of adsorption site [38]. The extent decrease of adsorption, particularly towards the end of experiment, indicates the possible monolayer of fluoride ions on the outer surface. Adsorption basically depends on the particle size, the smaller the particle size, the greater the surface area and the greater the adsorption capacity per unit mass of adsorbent [21]. The rate of adsorption is a function of the initial concentration of the adsorbate, which makes it an important factor to be considered for effective adsorption [21]. The Ca-pretreated lichen also showed higher percentage of removal with increasing adsorbent dose. Increase in the removal efficiency with simultaneous increasing adsorbent dose is due to the increase in surface area and hence more active sites were available for the adsorption of fluoride [34, 39]. Moreover, results also suggest that with increasing adsorbent dose, $q_{e}$ value gradually decreases for both lichen and Ca-pretreated lichen. Therefore, the higher $q_{e}$ value at lower adsorbent dose is probably due to faster saturation of adsorption sites [4].

\section{The Effect of Stirring Rate (rpm)}

Studies on the effect of stirring rate were conducted by varying speeds from 150 to $350 \mathrm{rpm}$ at optimum $\mathrm{pH}$ for lichen is 8 and Ca-pretreated lichen is 6 with adsorbent dose $0.1 \mathrm{~g}$ (Fig. 7a) and $0.6 \mathrm{~g}$, respectively (Fig. 7b). The study result revealed that the removal of fluoride was decreased with increasing stirring rate from 250 to $350 \mathrm{rpm}$ for lichen (Fig. 7a). The maximum $79.3 \%$ removal was recorded for lichen at $250 \mathrm{rpm}$ (Fig. 7a) and Ca-pretreated lichen $(96.44 \%)$ at $350 \mathrm{rpm}$ (Fig. 7b). The removal of fluoride increased with increasing agitation speed is probably due to film diffusion or pore diffusion which again depends on the amount of agitation in the system [29]. If relatively little agitation occurs between the particles and fluid, 
Fig. 9 a Effect of particle size on the removal of fluoride by using lichen (initial fluoride concentration of $5.0 \mathrm{mg} / \mathrm{L} ; \mathrm{pH}$ of 8; adsorbent dose of $0.1 \mathrm{~g} /$ $100 \mathrm{~mL}$; contact time of $60 \mathrm{~min}$; stirring rate of $250 \mathrm{rpm}$; temperature of $313 \mathrm{~K}$ ). b Effect of particle size on the removal of fluoride by using Ca-pretreated lichen (initial fluoride concentration of $5.0 \mathrm{mg} / \mathrm{L}$; $\mathrm{pH}$ of 8 ; adsorbent dose of $0.6 \mathrm{~g} /$ $100 \mathrm{~mL}$; contact time of $60 \mathrm{~min}$; stirring rate of $350 \mathrm{rpm}$; temperature of $313 \mathrm{~K}$ )
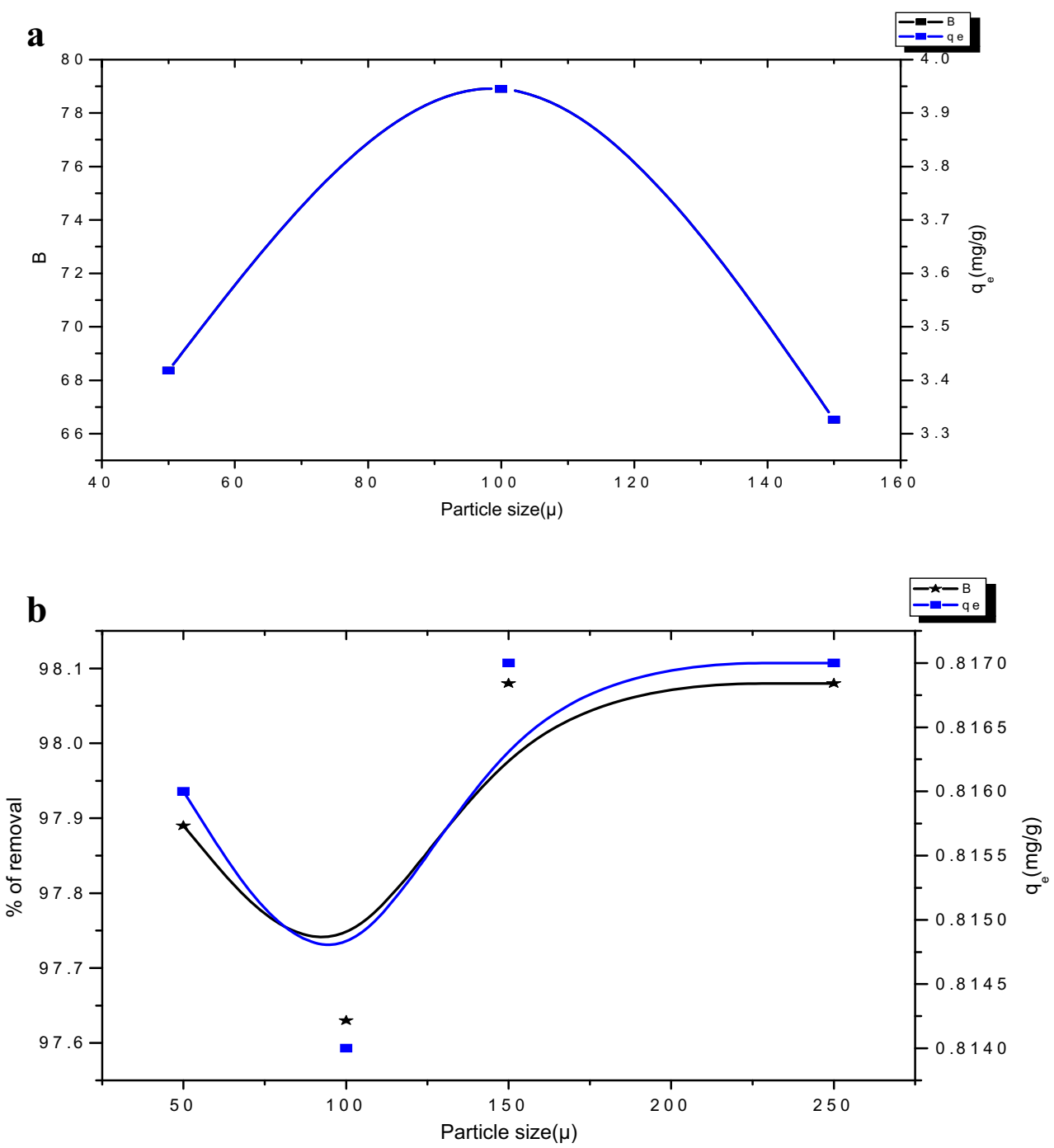

the surface film of liquid around the particle will be thick and film diffusion will likely be the rate-limiting step. Pertinent literature [40] also highlighted that the mass transfer rate increases with increase in stirring rate. They also suggested that the boundary layer thickness decreases with increased stirring speed which results in a reduction in surface film resistance.

\section{The Effect of Contact Time (min)}

The effect of contact time on adsorption of fluoride was also investigated. Research indicates [27] that contact time is a valuable operating parameter which directly affect on the biosorption capacity of the adsorbent. In this study, results indicate that fluoride removal increased with increasing contact time for both lichen and Ca-pretreated lichen (Fig. 8a b). Initially, there may have active binding sites for both the adsorbents (lichen and Ca-pretreated lichen), and consequently large amount of fluoride ions was bound rapidly onto the adsorption [41]. However, after $120 \mathrm{~min}$, it approaches a constant value denoting attainment of equilibrium.

\section{The Effect on Particle Size $(\mu \mathrm{m})$}

Adsorption is surface phenomenon and the extent of adsorption is expected to be proportional to the surface area available for adsorption [21]. In the present work, the effect of particle size was investigated by using average particle size $(50,100$, and $150 \mu \mathrm{m}$ ) under identical condition of initial concentration of both lichen and Ca-pretreated lichen are $35 \mathrm{ppm}$ and adsorbent dose $0.1 \mathrm{~g} / 100 \mathrm{~mL}$ for lichen and $0.6 \mathrm{~g} / 100 \mathrm{~mL}$ for $\mathrm{Ca}-$ pretreated lichen. The variation of the particle size on fluoride removal was initially less but maximum removal was recorded by particle size $100 \mu \mathrm{m}$ (78.9 \%) (Fig. 9a). Again, the percentage of removal decreases at $150 \mu \mathrm{m}$. But Capretreated lichen showed increasing tendency of fluoride removal with increasing particle size after $100 \mu \mathrm{m}$ (Fig. 9b). 
Fig. 10 a Effect of initial concentration of fluoride solution by using lichen $(\mathrm{pH}$ of 8 ; adsorbent dose of $0.1 \mathrm{~g} / 100 \mathrm{~mL}$; contact time of $60 \mathrm{~min}$; particle size of $100 \mu \mathrm{m}$; stirring rate of $250 \mathrm{rpm}$; temperature of $313 \mathrm{~K}$ ). b Effect of initial concentration of fluoride solution by using Ca-pretreated lichen ( $\mathrm{pH}$ of 8; adsorbent dose of $0.6 \mathrm{~g} / 100 \mathrm{~mL}$; contact time of $60 \mathrm{~min}$; stirring rate of $250 \mathrm{rpm}$; particle size of $150 \mu \mathrm{m}$; temperature of $313 \mathrm{~K}$ )
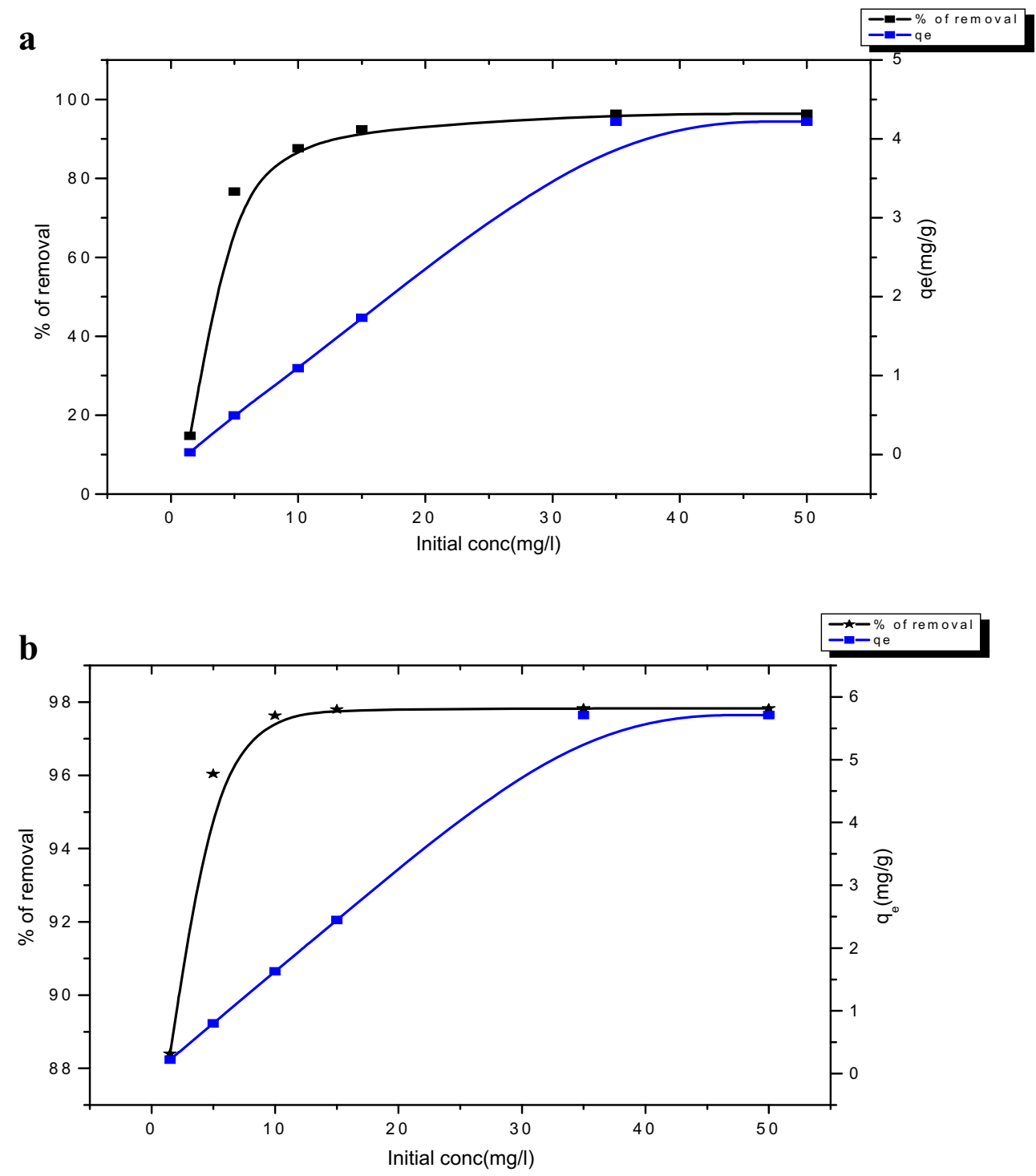

\section{The Effect of Initial Concentration (mg/L)}

The effect of different initial concentration of fluoride on to lichen and Ca-pretreated lichen is presented in Fig. 10a, b. The percentage removal of fluoride increased with increasing initial fluoride concentration and showed equilibrium after reaching maximum. This can be attributed that all adsorbent have a limited number of active sites, which become saturated at a certain concentration. Moreover, for fixed adsorbent dose, the total available adsorption sites were limited, which become saturated at higher concentration [34]. The adsorbents lichen and Ca-pretreated lichen showed 94.50 and $97.83 \%$ fluoride removal, respectively (Fig. 10a, b). The results also indicate that the adsorption capacity of lichen and Ca-pretreated lichen are 4.34 and $6.21 \mathrm{mg} / \mathrm{g}$, respectively.

\section{The Effect of Temperature $\left({ }^{\circ} \mathrm{C}\right)$}

Temperature is one of the most important variables for adsorption process. Increasing temperature modifies the equilibrium capacity of the adsorption of particular adsorbent. Therefore, the effect of temperature on fluoride adsorption by lichen and Ca-pretreated lichen was investigated (Fig. 11, b). As seen from the figure, the percentage removal of fluoride decreases with increasing temperature for both the adsorbents. Probably due to increasing temperature, the interaction force between solute and sorbent decreases and as a result, the solute was difficult to be adsorbed [42]. Moreover, at higher temperature, the thickness of the boundary layer decreases due to increased tendency of the molecules to escape from the adsorbent surface to the solution phase $[27,43]$. 

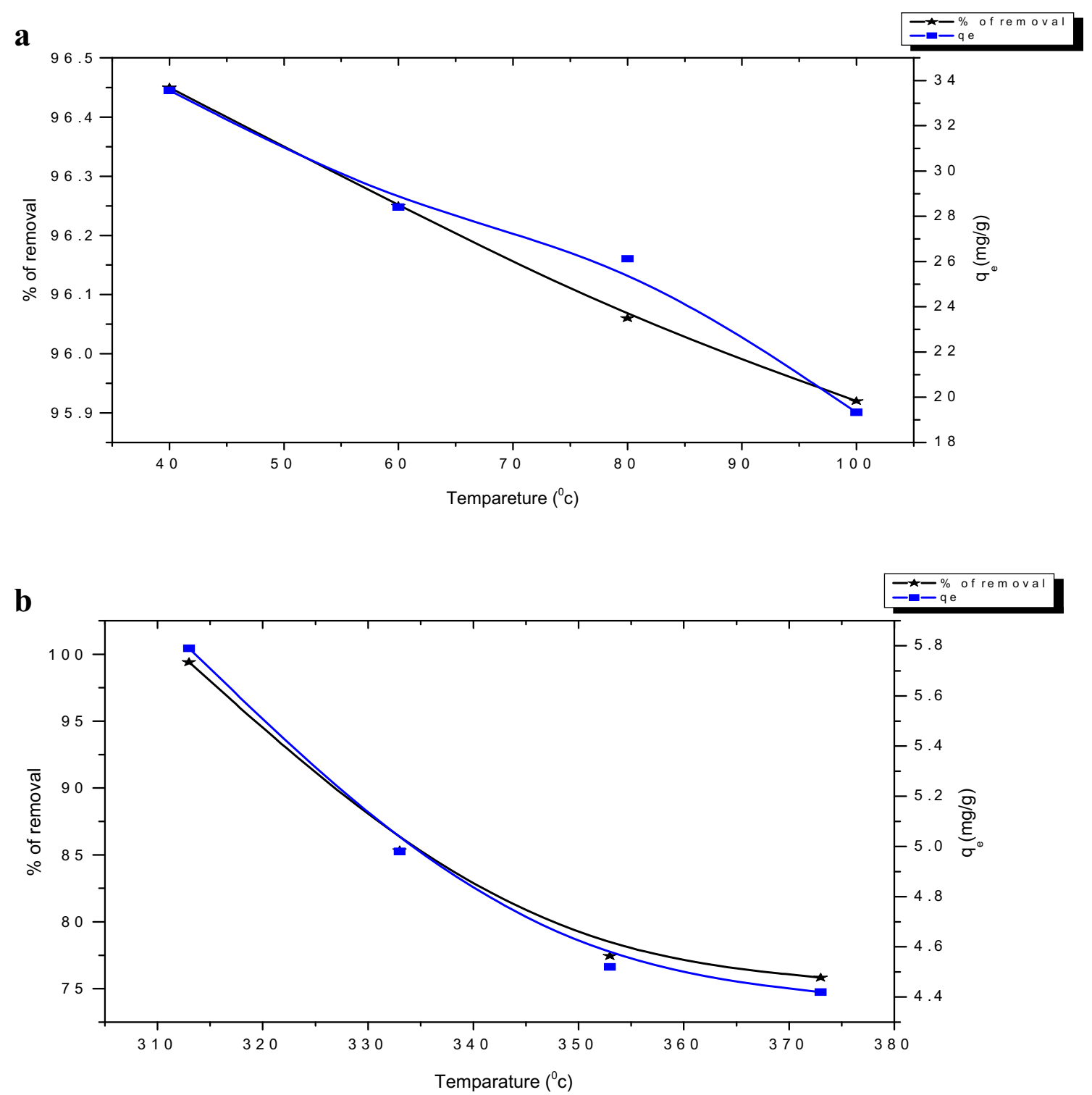

Fig. 11 a Effect of temperature on removal of fluoride by lichen (initial fluoride concentration of $5.0 \mathrm{mg} / \mathrm{L}$; $\mathrm{pH}$ of 8 ; adsorbent dose of $0.1 \mathrm{~g} /$ $100 \mathrm{~mL}$; particle size of $100 \mu \mathrm{m}$; stirring rate of $250 \mathrm{rpm}$; contact time of $120 \mathrm{~min}$ ). $\mathbf{b}$ Effect of temperature on removal of fluoride by Ca-pretreated lichen (initial fluoride concentration of $5.0 \mathrm{mg} / \mathrm{L} ; \mathrm{pH}$ of 8 ; adsorbent dose of $0.6 \mathrm{~g} / 100 \mathrm{~mL}$; particle size of $150 \mu \mathrm{m}$; stirring rate of $350 \mathrm{rpm}$; contact time of $120 \mathrm{~min}$ )

\section{Adsorption Isotherm Study}

The Langmuir, Freundlich, D-R, and Tempkin isotherm models are commonly used for waste water treatment application. For the adsorbent, the parameter and correlation coefficient obtained from the plots of Langmuir $\left(1 / \mathrm{q}_{\mathrm{e}}\right.$ vs. $\left.1 / \mathrm{c}_{\mathrm{e}}\right)$, Freundlich $\left(\log \mathrm{q}_{\mathrm{e}}\right.$ vs. $\left.\log \mathrm{c}_{\mathrm{e}}\right)$, D-R $\left(\ln \mathrm{q}_{\mathrm{e}}\right.$ vs. $\varepsilon^{2}$ ), and Tempkin ( $\operatorname{lnc}_{\mathrm{e}}$ vs. qe) are listed in Table 4. From Table 4, it has been found that Langmuir, Freundlich, and D-R isotherm models were excellent fitted to the experimental data with high correlation coefficient at lower temperature $(313 \mathrm{~K})$ except Tempkin isotherm that is fitted at higher temperature $(353 \mathrm{~K})$ use for lichen. The calculated isotherm parameters along with correlation coefficients are given in Table 4. The magnitude of the Langmuir constant "b" has small values $(0.081-1.643 \mathrm{~L} / \mathrm{mg})$, which indicates a low heat of adsorption. In order to distinguish between physical and chemical sorption on the heterogeneous surface, the equilibrium were tested with D-R isotherm model [36]. The correlation coefficient was found comparatively much higher than Freunlich and Langmuir isotherms (Table 4). The constant $\beta$ gives an idea about the mean free energy $E(\mathrm{~kJ} / \mathrm{mol})$ of adsorption per mol of the adsorbate when it is transferred to 
the surface of the solute from infinity in the solution and can be calculated using the following relationship Eq. (7) [44]:

$E=\frac{1}{\sqrt{2 \beta}}$

The value of this parameter can be given information about the type of adsorption mechanism. If the magnitude of $E$ is between 8 and $16 \mathrm{KJ} / \mathrm{mol}$, the sorption process is supposed to precede viz. chemisorptions, while for values of $E$ less than 8 $\mathrm{KJ} / \mathrm{mol}$, the sorption process is of physical in nature [44]. Similar isotherm was also used for Ca-pretreated lichen (Table 5). The results revealed that D-R and Tempkin isotherms were best fitted with higher goodness of fit at all studied temperature (313-373 K). But Langmuir and Freundlich isotherms do not show good fitness in lower temperature, which indicates that the adsorption process on Ca-pretreated lichen is neither monolayer nor multilayer adsorption. The Langmuir constant $b$ has small values, which indicates a low heat of adsorption. From the Freundlich isotherm, the " $n$ " value increased with the increasing the temperature, which indicates the most favorable adsorption at high temperature. The $R^{2}$ value of D-R and Tempkin equation showed that the steady decrease with increase in temperature. Again from D-R isotherm, $E$ value calculated from the constant $\beta$ less than $8 \mathrm{KJ} / \mathrm{mol}$; therefore, it can be suggested that adsorption process is purely physical adsorption (Table 5) [45].

Analysis of equilibrium data is important for developing an equation that can be used to compare different materials under different operational condition and to design and optimized an operating procedure [46]. From the Freundlich isotherm, the $n$ value increased with the increasing the temperature, which indicates the increase of bond strength between adsorbate and adsorbent and it also indicates the adsorbent surface to be of heterogeneous [47]. On the other hand, the magnitude of $E$ less than $8 \mathrm{KJ} / \mathrm{mol}$ for all studied temperature indicating that adsorption mechanism of fluoride on lichen was physical in nature [48]. The Tempkin isotherm showed correlation coefficient value at high (0.974) at temperature $353 \mathrm{~K}$ but lower $(0.951)$ at $333 \mathrm{~K}$ that means it indicates the linear dependence of the heat of adsorption of fluoride on lichen. The linearity may be due to repulsion between adsorbate species and two intrinsic surfaces heterogeneity. Similar phenomenon has been observed by Sinha et al. [49].

\section{Adsorption Kinetics Study}

Pseudo-first-order, pseudo-second-order, and intraparticle diffusion model were used to fit the experimental data for fluoride adsorption to determine the adsorption mechanism and potential rate controlling steps. The results revealed that pseudo-first-order equation did not provide an accurate fit to 
Table 5 Adsorption isotherm model of ca-pretreated lichen

\begin{tabular}{|c|c|c|c|c|c|c|c|c|c|c|c|c|c|c|c|}
\hline \multirow{2}{*}{$\begin{array}{l}\text { Temp. } \\
\text { (K) }\end{array}$} & \multirow{2}{*}{$\begin{array}{l}q_{\exp }(\mathrm{mg} \\
\left.\mathrm{gm}^{-1}\right)\end{array}$} & \multicolumn{4}{|c|}{ Langmuir isotherm } & \multicolumn{3}{|c|}{ Freundlich isotherm } & \multicolumn{4}{|c|}{ D-R isotherm } & \multicolumn{3}{|c|}{ Tempkin isotherm } \\
\hline & & $q_{m}\left(\mathrm{mg} \mathrm{g}^{-1}\right)$ & $k_{L}(\mathrm{~L} / \mathrm{mg})$ & $R_{L}$ & $R^{2}$ & $\begin{array}{l}\mathrm{k}_{\mathrm{F}}\left(\mathrm{mg}^{1-(1 / \mathrm{n})}\right. \\
\left.\mathrm{L}^{1 / \mathrm{n}} \mathrm{g}^{-1}\right)\end{array}$ & $n$ & $R^{2}$ & $q_{m}\left(\mathrm{mg} \mathrm{g}^{-1}\right)$ & $\beta\left(\mathrm{mm} \mathrm{ol}^{2} \mathrm{~J}^{-2}\right)$ & $\mathrm{E}\left(\mathrm{KJmol}^{-1}\right)$ & $R^{2}$ & $B_{1}$ & $\mathrm{k}_{\mathrm{T}}\left(\mathrm{L} \min ^{-1}\right)$ & $R^{2}$ \\
\hline 313 & 5.71 & 1.72 & 1.41 & 0.12 & 0.90 & 12.76 & 0.55 & 0.77 & 10.22 & 0.11 & 2.11 & 0.99 & 3.63 & 6.25 & 0.90 \\
\hline 333 & 5.46 & 0.78 & 0.75 & 0.04 & 0.83 & 2.03 & 0.62 & 0.93 & 5.87 & 0.21 & 1.54 & 0.98 & 2.69 & 2.92 & 0.95 \\
\hline 353 & 5.35 & 0.84 & 0.61 & 0.05 & 0.79 & 1.54 & 0.66 & 0.89 & 5.09 & 0.22 & 1.51 & 0.98 & 2.54 & 2.68 & 0.97 \\
\hline 373 & 5.24 & 0.78 & 0.43 & 0.06 & 0.50 & 0.93 & 0.64 & 0.79 & 4.15 & 0.36 & 1.18 & 0.98 & 2.58 & 1.87 & 0.96 \\
\hline
\end{tabular}

Table 6 Kinetics study for adsorption of fluoride onto lichen

\begin{tabular}{|c|c|c|c|c|c|c|c|c|c|c|c|}
\hline \multirow[t]{2}{*}{ Temp. (K) } & \multirow[t]{2}{*}{$\mathrm{qe}_{\exp }(\mathrm{mg} / \mathrm{g})$} & \multicolumn{3}{|c|}{ Pseudo-first-order model } & \multicolumn{4}{|c|}{ Pseudo-second-order model } & \multicolumn{3}{|c|}{ Intraparticle diffusion model } \\
\hline & & $q_{e}(\mathrm{mg} / \mathrm{g})$ & $K_{1}\left(\min ^{-1}\right)$ & $R^{2}$ & $q_{e}(\mathrm{mg} / \mathrm{g})$ & $\mathrm{K}_{2}\left(\mathrm{~g} \mathrm{mg}^{-1} \min ^{-1}\right)$ & $\mathrm{h}\left(\mathrm{mg} \mathrm{g}^{-1} \min ^{-1}\right)$ & $R^{2}$ & $K_{i}\left(\mathrm{mg} \mathrm{g}^{-1} \min ^{-0.5}\right)$ & $I$ & $R^{2}$ \\
\hline 313 & 3.72 & 0.32 & 0.01 & 0.69 & 3.98 & 0.08 & 0.29 & 0.98 & 0.11 & 2.31 & 0.74 \\
\hline 333 & 3.56 & 0.47 & 0.01 & 0.38 & 3.88 & 0.02 & 0.23 & 0.98 & 0.14 & 1.89 & 0.88 \\
\hline 353 & 3.42 & 0.62 & 0.01 & 0.52 & 3.38 & 0.01 & 0.15 & 0.94 & 0.16 & 1.42 & 0.89 \\
\hline 373 & 3.25 & 0.76 & 0.01 & 0.36 & 3.91 & 0.01 & 0.11 & 0.97 & 0.19 & 0.89 & 0.86 \\
\hline
\end{tabular}

the experimental data for both the adsorbents. The first-order rate constant $K_{1}$ and the correlation coefficient $R^{2}$ and the theoretical and experiment equilibrium adsorption capacity was given in Tables 6 and 7. The $\log \left(q_{e}-q_{t}\right)$ vs. $t$ were linear with $R^{2}$ varying from $0.3569-0.6907$ for lichen and 0.2460.568 for Ca-pretreated biomass; however, the theoretical and experimental equilibrium adsorption capacity, $q_{e}$ obtained from the plots varied widely. Suggesting that pseudo-firstorder model was not appropriate for describing the adsorption kinetic of fluoride onto lichen and Ca-pretreated lichen. Further, the kinetic data was fitted to the pseudo-secondorder equation, the plot of $t / q_{t}$ vs. $t$ at different temperature shown in Tables 6 and 7. Contrary to the pseudo-first order, the fitting of the kinetic data in the pseudo-second-order equation showed excellent linearity with high correlation coefficient over the temperature ranges from 313 to $373 \mathrm{~K}$ [36]. The data obtained from the pseudo-second-order kinetic model at the four different temperatures is tabulated in Tables 6 and 7.
The Weber and Morris plots for the adsorption of fluoride on lichen and Ca-pretreated lichen at different temperature were multimodal with three distinct regions (figure not shown). The initial curve region corresponds to the external surface uptake, the second stage relates the gradual uptake reflecting intraparticle diffusion as the rate limiting state, and final plateau region indicates equilibrium uptake. From the structural pattern of two adsorbents, it is clear that none of the figure showed the line passing through the origin. Therefore, it may be concluded that the kinetics of both the adsorbents may be controlled by other suitable factor other than intraparticle diffusion model.

\section{Activation Energy and Thermodynamics Study}

From the pseudo-second-order rate constant $k_{2}$ (Tables 6 and 7), the activation energy $E_{a}$ for the adsorption of fluoride on both lichen and Ca-pretreated biomass was

Table 7 Kinetics study for adsorption of fluoride onto Ca-pretreated lichen

\begin{tabular}{|c|c|c|c|c|c|c|c|c|c|c|c|}
\hline \multirow[t]{2}{*}{ Temp. (K) } & \multirow[t]{2}{*}{$\mathrm{qe}_{\exp }(\mathrm{mg} / \mathrm{g})$} & \multicolumn{3}{|c|}{ Pseudo-first-order model } & \multicolumn{4}{|c|}{ Pseudo-second-order model } & \multicolumn{3}{|c|}{ Intraparticle diffusion model } \\
\hline & & $q_{e}(\mathrm{mg} / \mathrm{g})$ & $K_{1}\left(\min ^{-1}\right)$ & $R^{2}$ & $q_{e}(\mathrm{mg} / \mathrm{g})$ & $K_{2}\left(\mathrm{~g} \mathrm{mg}^{-1} \min ^{-1}\right)$ & $h\left(\mathrm{mg} \mathrm{g}^{-1} \min ^{-1}\right)$ & $R^{2}$ & $K_{\mathrm{i}}\left(\mathrm{mg} \mathrm{g}^{-1} \min ^{-0.5}\right)$ & $I$ & $R^{2}$ \\
\hline 313 & 0.801 & 0.001 & 0.041 & 0.568 & 0.802 & 2.188 & 1.407 & 0.999 & 0.002 & 0.773 & 0.609 \\
\hline 333 & 0.758 & 0.057 & 0.002 & 0.241 & 0.949 & 0.065 & 0.058 & 0.952 & 0.012 & 0.624 & 0.934 \\
\hline 353 & 0.751 & 0.042 & 0.017 & 0.510 & 0.785 & 0.168 & 0.103 & 0.998 & 0.017 & 0.550 & 0.966 \\
\hline 373 & 0.735 & 0.073 & 0.013 & 0.369 & 0.735 & 0.1 & 0.063 & 0.998 & 0.027 & 0.410 & 0.966 \\
\hline
\end{tabular}


Table 8 Activation energy and thermodynamic model of lichen for adsorption of fluoride

\begin{tabular}{lllllll}
\hline$E_{a}\left(\mathrm{kJmol}^{-1}\right)$ & \multicolumn{2}{c}{$\Delta \mathrm{G}^{0}\left(\mathrm{kJmol}^{-1}\right)$} & & $\Delta \mathrm{H}^{0}\left(\mathrm{kJmol}^{-1}\right)$ & $\Delta \mathrm{S}^{0}\left(\mathrm{kJmol}^{-1}\right)$ \\
\cline { 2 - 5 } & $313 \mathrm{k}$ & $333 \mathrm{k}$ & $353 \mathrm{k}$ & $373 \mathrm{k}$ & \\
\hline 13.406 & -8.801 & -8.678 & -8.561 & -8.491 & -10.679 & -0.006 \\
\hline
\end{tabular}

\begin{tabular}{lllllll}
\hline$E_{a}\left(\mathrm{kJmol}^{-1}\right)$ & \multicolumn{2}{l}{} & $\Delta \mathrm{G}^{0}\left(\mathrm{kJmol}^{-1}\right)$ & & $\Delta \mathrm{H}^{0}\left(\mathrm{kJmol}^{-1}\right)$ & $\Delta \mathrm{S}^{0}\left(\mathrm{kJmol}^{-1}\right)$ \\
\cline { 2 - 5 } & $313 \mathrm{k}$ & $333 \mathrm{k}$ & $353 \mathrm{k}$ & $373 \mathrm{k}$ & & \\
\hline 32.89 & -17.891 & -17.751 & -17.611 & -17.471 & -20.082 & -0.007 \\
\hline
\end{tabular}

Table 9 Activation energy and thermodynamic model of capretreated lichen for adsorption of fluoride all temperature indicate the feasibility of the processes and the spontaneous nature of fluoride adsorption on these bioadsorbent (Tables 8 and 9).

The increment of the value of $\Delta \mathrm{G}^{0}$ with increasing temperature suggests that the adsorption is favorable at lower temperature. From the negative value of $\Delta \mathrm{H}^{0}$ for all the adsorbent, it can be suggested that the adsorption phenomenon is exothermic in nature. The negative values of $\Delta S^{0}$ suggest that the process is enthalpy driven [50].

\section{Regeneration of Adsorbent}

So far, as waste water purification is concern, adsorption technology is one of the most economical processes when exhausted adsorbent is regenerable [50]. Regeneration of adsorbent helps to reduce environmental contamination from the
Fig. 12 Regeneration of exhausted lichen and $\mathrm{Ca}-$ pretreated lichen at different $\mathrm{pH}$

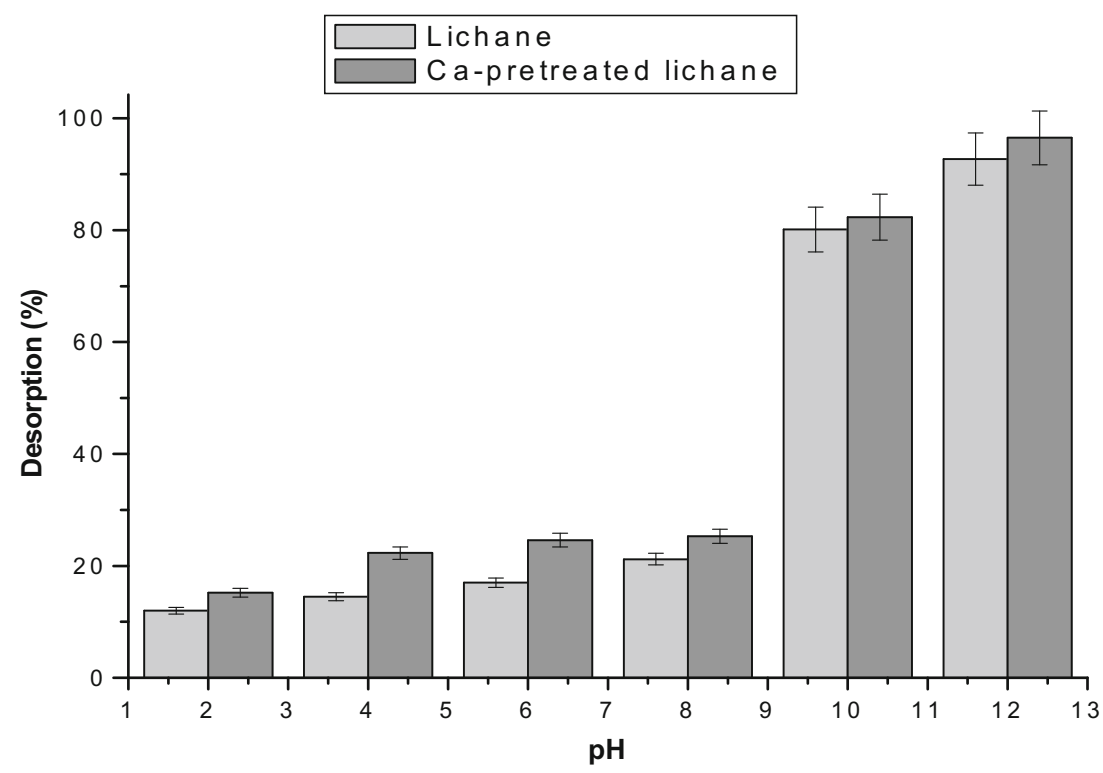


Table 10 Comparison between various adsorbents used for fluoride removal

\begin{tabular}{|c|c|c|}
\hline Name of adsorbent & $\begin{array}{l}\text { Adsorption capacity } \\
(\mathrm{mg} / \mathrm{g})\end{array}$ & Reference \\
\hline $\begin{array}{l}\text { Zirconium(iv)-impregnated } \\
\text { groundnut (Anacardium } \\
\text { occidentale) shell carbon }\end{array}$ & 2.23 & {$[51]$} \\
\hline Al-modified hydroxyapatite (Al-HAP) & 32.57 & {$[52]$} \\
\hline Magnesia loaded fly ash cenospheres & 6.0 & {$[53]$} \\
\hline Coconut fiber dust (CFD) & 12.66 & \multirow[t]{4}{*}[21]{} \\
\hline CFD-1 & 25.64 & \\
\hline CFD-2 & 38.46 & \\
\hline CFD-3 & & \\
\hline Modified granules (Ce(III)-MAG) & 4.8 & {$[54]$} \\
\hline Aluminum alginate beads & 75.2 & {$[55]$} \\
\hline Rice husk ash (RHA) by coating $\mathrm{Al}(\mathrm{OH})_{3}$ & $9-10$ & {$[56]$} \\
\hline $\begin{array}{l}\text { Zirconium impregnated cashew nut } \\
\text { (Anacardium occidental) shell } \\
\text { carbon }\end{array}$ & 1.83 & {$[57]$} \\
\hline Eichhormia crassipes biomass & 0.52 & [49] \\
\hline $\begin{array}{l}\text { Carbon at } 300{ }^{\circ} \mathrm{C} \\
\text { Aluminum impregnated coconut } \\
\text { fiber ash }\end{array}$ & 3.192 & {$[50]$} \\
\hline $\begin{array}{l}\text { Pecan (Carya illinoinensis) nut shell carbon modified with egg shells } \\
\text { calcium }\end{array}$ & $1.61-2.51$ & {$[58]$} \\
\hline $\begin{array}{l}\text { Scandinavia spruce wood modified with aluminum and iron oxides } \\
\text { carbonized at }\end{array}$ & 5.67 & {$[59]$} \\
\hline $900{ }^{\circ} \mathrm{C}$ & & \multirow{3}{*}{$\begin{array}{r}\text { Present } \\
\text { study }\end{array}$} \\
\hline Lichen & 0.81 & \\
\hline Ca-pretreated lichen & 1.72 & \\
\hline
\end{tabular}

Table 11 Physico-chemical characteristics of groundwater samples

\begin{tabular}{ccccl}
\hline Parameters & \multicolumn{1}{l}{ Sarsa } & \multicolumn{1}{l}{ Tarapur } & " $”$ value & $\begin{array}{l}\text { Significant } \\
\text { level }\end{array}$ \\
\hline $\mathrm{F}^{-}$ & $5.4 \pm 0.200$ & $4.7 \pm 0.361$ & 7.000 & $P<0.020$ \\
$\mathrm{pH}$ & $7.19 \pm 0.347$ & $7.28 \pm 0.798$ & 0.16 & $P<0.885$ \\
$\mathrm{EC}$ & $5.34 \pm 0.641$ & $5.08 \pm 0.072$ & 0.73 & $P<0.544$ \\
$\mathrm{TH}$ & $588 \pm 1.73$ & $546.8 \pm 1.63$ & 21.64 & $P<0.002$ \\
$\mathrm{TA}$ & $170 \pm 0.92$ & $168 \pm 8.77$ & 0.44 & $P<0.702$ \\
$\mathrm{Cl}$ & $508.8 \pm 8.7$ & $478.8 \pm 20.9$ & 2.08 & $P<0.173$ \\
$\mathrm{HCO}_{3}{ }^{-}$ & $148.7 \pm 2.74$ & $149.8 \pm 2.33$ & 0.38 & $P<0.743$ \\
$\mathrm{Ca}$ & $122.7 \pm 0.61$ & $163.5 \pm 3.15$ & 27.1 & $P<0.001$ \\
$\mathrm{Mg}$ & $87.5 \pm 0.954$ & $91.2 \pm 0.819$ & 4.74 & $P<0.042$ \\
$\mathrm{SO}_{4}{ }^{2-}$ & $344.8 \pm 0.987$ & $389 \pm 1.277$ & 102.77 & $P<0.000$ \\
$\mathrm{Fe}^{-}$ & $1.43 \pm 0.096$ & $1.16 \pm 0.046$ & 3.58 & $P<0.07$ \\
$\mathrm{PO}_{4}{ }^{3-}$ & $1.03 \pm 0.078$ & $0.97 \pm 0.027$ & 1.96 & $P<0.188$ \\
$\mathrm{TDS}^{+}$ & $390 \pm 14.7$ & $298 \pm 39.0$ & 3.99 & $P<0.057$ \\
$\mathrm{Na}^{+}$ & $182.4 \pm 0.56$ & $177.6 \pm 3.33$ & 2.79 & $P<0.108$ \\
$\mathrm{~K}^{+}$ & $88.5 \pm 0.624$ & $97.4 \pm 0.889$ & 11.75 & $P<0.007$ \\
$\mathrm{SiO}_{2}$ & $87.2 \pm 0.719$ & $84.2 \pm 0.904$ & 5.75 & $P<0.029$ \\
\hline
\end{tabular}

Units of all water parameters are expressed in $\mathrm{mg} / \mathrm{L}$ except $\mathrm{pH}$ and $\mathrm{EC}$ $(\mu \mathrm{S} / \mathrm{cm})$ discarded adsorbents. In this study, the desorption was carried out with 1 and $6 \mathrm{~g} / \mathrm{L}$ fluoride adsorbed by lichen and Capretreated lichen, respectively, at varying $\mathrm{pH}$ by using $0.1 \mathrm{M}$ $\mathrm{NaOH}$. Figure 12a, b shows that up to $\mathrm{pH} 7.5$ and 8.5 for lichen and Ca-pretreated lichen, respectively, showed no leaching of fluoride. However, desorption of fluoride occur better at $\mathrm{pH}$ greater than 7.5 and 8.5 and reached maximum 92.7 and $96.5 \%$ at $\mathrm{pH} 12$ for lichen and Ca-pretreated lichen, respectively (Fig. 12a, b). At higher $\mathrm{pH}$, regeneration of adsorbent is high due to excess $\mathrm{OH}-$ accumulation on fluorideloaded lichen and Ca-pretreated lichen [50]. Almost similar regeneration of adsorbent was reported by Bhaumik and Mondal [34].

\section{Comparative Adsorption Capacity}

The adsorption capacity of the other published literature clearly demonstrate that the present adsorbent, Ca-pretreated lichen showed much better performance than Eichhornia crassipes and pecan nut shell (Table 10). But Al-modified hydroxyapatite, coconut fiber dust, aluminum alginate beads, and rice 
husk ash showed much better performance than Ca-pretreated lichen.

\section{Defluoridation from Field Sample}

Twenty field samples were collected from the two fluoride affected villages of Khoyrasol Block, Birbhum district. The physico-chemical characterization of the collected water samples has been presented in Table 11. The removal of fluoride from the samples of Sarsa and Tarapur was achieved by application Ca-pretreated lichen as 84.0 and $83.25 \%$, respectively. Defluoridation of samples of groundwater was conducted without adjusting $\mathrm{pH}$ of the experimental samples at the rate $6.0 \mathrm{~g} / \mathrm{L}$ Ca-pretreated lichen under identical experimental conditions of the equilibrium batch adsorption study. Interestingly, fluoride concentration of two villages of Sarsa and Tarapur reduced to 0.86 and $0.79 \mathrm{mg} / \mathrm{L}$, respectively, without adjusting $\mathrm{pH}$ and the fluoride level below WHO guideline value in drinking water [21].

\section{Conclusion}

From the entire adsorption study, it has been found that the biomass of lichen showed fluoride removal about $94.50 \%$ at higher $\mathrm{pH}$ 8. On the other hand, Ca-pretreated lichen showed much higher removal efficiency $(97.83 \%)$ at lower $\mathrm{pH} 6$, but higher adsorbent dose, stirring rate, and contact time than pure lichen. The study result showed that lichen and Ca-pretreated lichen good agreement with D-R equation with very high goodness of fit. The nature of adsorption of fluoride on both lichen and Ca-pretreated biomass was physical adsorption as inferred from the Dubinin-Radushkevich (D-R) isotherm model. In case of Ca-pretreated lichen, experimental equilibrium data provided best fit with the Langmuir isotherm model, indicating monolayer sorption on a homogenous surface. The monolayer sorption capacity decreased with increase in temperature in the range 313-373 K. Tempkin isotherm also showed best fitted at all temperature range. The kinetic model indicates that lichen and Ca-pretreated lichen were good fitted with pseudo-second-order kinetic model with high correlation of coefficient value at lower temperature. Intra-particle diffusion was not the sole rate controlling factors for adsorption of fluoride by both lichen and Ca-pretreated lichen biomass. Thermodynamics study indicates that all the reaction is exothermic in nature that is why adsorption process is favorable at lower temperature range. The activation energy of the adsorption process $\left(E_{a}\right)$ was found to be 13.406 and $32.89 \mathrm{~kJ} \mathrm{~mol}^{-1}$ for lichen and Ca-pretreated lichen biomass, respectively. The present findings suggest that lichen biomass may be used as an inexpensive and effective adsorbent with Ca-pretreated lichen for the removal of fluoride from aqueous solutions.
Acknowledgments Authors would like to express their sincere respect to Dr. Jayanta Kumar Data for his constant encouragement and moral support. Authors would also like to extend their sincere thanks to all faculty and office staff for their moral support to conduct such extensive work.

\section{References}

1. WHO (1984) Fluorine and Fluorides. Environmental Health Criteria 36. World Health Organisation, Geneva.

2. ATSDR (1993) Toxicological profile for fluorides, hydrogen fluoride, and fluorine. Atlanta,

3. Aboua KN, Yobouet YA, Yao KB, Gon DL, Trokourey A (2015) Investigation of dye adsorption onto activated carbon from the shells of Macore fruit. J Environ Manag 156:10-14

4. Chen N, Feng C, Li M (2014) Fluoride removal on Fe-Al impregnated granular ceramic adsorbent from aqueous solution. Clean Techn Environ Policy 16:609-617

5. WHO (2004) Guidelines for drinking-water quality, Recommendation, vol vol 1, 3rd edn. WHO, Geneva

6. Young M, Hashimoto T, Hosho N, Myoga H (1999) Fluoride removal in a fixed bed packed with granular calcite. Water Res 33: 3395-3402

7. Raichur AM, Basu MJ (2001) Adsorption of fluoride onto mixed rare earth oxides. Sep Purif Technol 24:121-127

8. Wang Y, Reardon EJ (2001) Activation and regeneration of a soil sorbent for defluoridation of drinking water. Appl Geochem 16: 531-539

9. Ricordel S, Taha S, Cisse I, Dorange G (2001) Heavy metals removal by adsorption onto peanut husks carbon: characterization, kinetics study and modeling. Sep Purif Tech 24(3):389-401

10. Pesavento M, Profumo A, Alberti G, Conti F (2003) Adsorption of lead(II) and copper(II) on activated carbon by complexation with surface functional groups. Anal Chim Acta 480:171-180

11. Mondal NK, Bhaumik R, Banerjee A, Datta JK, Baur T (2012a) A comparative study on the batch performance of fluoride adsorption by activated silica gel and activated rice husk ash. Inter J Environ Sci 2(3):1643-1661

12. Mondal NK, Bhaumik R, Baur T, Das B, Roy P, Datta JK (2012b) Studies on defluoridation of water by tea ash: an unconventional biosorbent. Chem Sci Trans 1(2):239-256

13. Karthikeyan G, Llango SS (2007) Fluoride sorption using Moringa Indica based activated carbon. Iran J Environ Health Sci Eng 4:2128

14. Turner BD, Binning PJ, Sloan SW (2010) Impact of phosphate on fluoride removal by calcite. Environ Eng Sci 27(8):643-650. doi:10.1089/ees.2009.0289

15. Mondal NK, Das B, Bhaumik R, Roy P (2012c) Calcareous soil as a promising adsorbent to remove fluoride from aqueous solution: equilibrium, kinetic and thermodynamic study. J Modern Chem Technol 3(3):1-21

16. Ghosh SB, Bhaumik R, Mondal NK (2016) Optimization study of adsorption parameters for removal of fluoride using aluminiumimpregnated potato plant ash by response surface methodology. Clean Techn Environ Policy. doi:10.1007/s10098-016-1097-z

17. Mondal NK, Roy A (2015) Novel use of rice husk carbon (a natural carbon matrix) for fluoride removal from aqueous solution. Morr J Chem 3(1):8-18

18. Bhatnagar M, Bhatnagar A, Jha S (2002) Interactive biosorption by microalgal biomass as a tool for fluoride. Fluoride 34:55-65

19. Mondal NK, Bhaumik R, Roy P, Das B, Datta JK (2013a) Investigation on fixed bed column performance of fluoride adsorption by sugarcane charcoal. J Environ Biol 34:1059-1064 
20. Mondal MK (2010) Removal of $\mathrm{Pb}(\mathrm{II})$ from aqueous solution by adsorption using activated tea waste. Korean J Chem Eng 27(1): 144-151

21. Bhaumik R, Mondal NK (2015) Adsorption of fluoride from aqueous solution by a new low-cost adsorbent: thermally and chemically activated coconut fiber dust. Clean Techn Environ Policy 17:21572172

22. Islam M, Patel RK (2007) Evaluation of removal efficiency of fluoride from aqueous solution using quick lime. J Hazard Mater 143:303-310

23. Bansiwal A, Thakre D, Labhshetwar N, Meshram S, Rayalu S (2009) Fluoride removal using lanthanum incorporated chitosan beads. Colloids Surf B 74(1):216-224

24. Lagergren S (1898) About the theory of so-called adsorption of soluble substances, der Sogenanntenadsorption geloster stoffe Kungliga Svenska Vetenska psalka de Miens Handlingar. 24: 1-39.

25. Ho YS, Mckay G (1999) The sorption of lead (II) ions on peat. Water Res 33:578-584

26. Weber WJ, Morris JC (1963) Kinetics of adsorption on carbon from solution. J Sanit Eng Div Am Soc Civ Eng 89:31-60

27. Sadaf S, Bhatti HN (2014) Evaluation of peanut husk as a novel, low cost biosorbent for the removal of Indosol Orange RSN dye from aqueous solutions: batch and fixed bed studies. Clean Techn Environ Policy 16:527-544. doi:10.1007/s10098-013-0653-Z

28. Kılıç Z, Atakol O, Aras S, Cansaran-Duman D, Emregul E (2014) Biosorption properties of zinc(II) from aqueous solutions by Pseudevernia Furfuracea (L.) Zopf. J Air Waste Manage Asso 64(10):1112-1121

29. Ekmekyapar F, Aslan A, Bayhan YK, Cakici A (2012) Biosorption of $\mathrm{Pb}$ (II) by nonliving lichen biomass of Cladonia rangiformis Hoffm. Int J Environ Res 6(2):417-424

30. Mahdavi S, Jalali M, Afkhami A (2015) Heavy metals removal from aqueous solutions by $\mathrm{Al}_{2} \mathrm{O}_{3}$ nanoparticles modified with natural and chemical modifiers. Clean Techn Environ Policy 17:85102

31. Yao YJ, Xu FF, Chen M, Xu ZX, Zhu ZW (2010) Adsorption behavior of methylene blue on carbon nanotubes. Bioresource Technol 101(9):3040-3046

32. Mungapati VS, Yarramuthi V, Nadavala SK, Alla SR, Abburi K (2009) Biosorption of $\mathrm{Cu}$ (II), Cd (II) and $\mathrm{Pb}(\mathrm{II})$ by Accacia leucocephala bark powder: kinetics, equilibrium and thermodynamics. Chem Eng J 157(2-3):357-365

33. Biswas K, Gupta K, Ghosh UC (2009) Adsorption of fluoride by hydrous iron (III)-tin (IV) bimetal mixed oxide from the aqueous solutions. Chem Eng J 149:196-206

34. Bhaumik R, Mondal NK (2014) Optimizing adsorption of fluoride from water by modified banana peel dust using response surface modelling approach. Appl Wat Sci. doi:10.1007/s13201-014- 0211-9

35. Mondal NK, Kundu M, Das K, Bhaumik R, Datta JK (2013b) Biosorption of fluoride from aqueous phase onto Aspergillus and its calcium-impregnated biomass and evaluation of adsorption kinetics. Fluoride 46:239-245

36. Chattoraj S, Mondal NK, Sadhukhan B, Roy P, Roy TK (2016) Optimization of adsorption parameters for removal of carbaryl insecticide using neem bark dust by response surfacemethodology. Water Conserv Sci Eng. doi:10.1007/s41101-016-0008-9

37. Prajapat R, Bhatnagar A, Gaur RK, Bajpai V (2010) Fluoride removal from water by sorbing on plant and fungal biomas. Inter $\mathrm{J}$ Biol Technol 1(1):43-46

38. Tembhurkar R, Dongre S (2006) Studies on fluoride removal using adsorption process. J Environ Sc Eng 48(3):151-156

39. Yadav AK, Abbassi R, Gupta A, Dadashzadeh M (2013) Removal of fluoride from aqueous solution and groundwater by wheat straw saw dust and activated carbon of sugarcane. Ecol Eng 52:211-218
40. Benefield LD, Judkins JF, Weand BL (1982) Process chemistry for water and wastewater treatment. New Jersey, Englewood Cliffs.

41. Alagumuthu G, Veeraputhiran V, Venkataraman R (2011) Fluoride sorption using cynodon dactylon-based activated carbon. Hem Ind 65(1):23-35

42. Crini G, Badot PM (2008) Application of chitosan, a natural aminopolysaccharide for dye removal from aqueous solutions by adsorption processes using batch studies: a review of recent literature. Prog Polym Sci 33:399-447

43. Sujana MG, Anand S (2010) Fluoride removal studies from contaminated ground water by using bauxite. Desalination 267(2-3): 222-227

44. Tuzen M, Sari A (2010) Biosorption of selenium from aqueous solution by green algae (Cladophora Hutchinsiae) biomass: equilibrium, thermodynamic and kinetic studies. Chem Eng J 158:200206

45. Mondal NK, Bhaumik R, Datta JK (2016) Fluoride adsorption by calcium carbonate activated alumina and activated sugarcane ash. Environ Process. doi:10.1007/s40710-016-0130-x

46. Parab H, Joshi S, Shenoy N, Lali A, Sarma US, Sudersanan M (2006) Determination of kinetic and equilibrium parameters of the batch adsorption of $\mathrm{Co}(\mathrm{II}), \mathrm{Cr}(\mathrm{III})$ and $\mathrm{Ni}(\mathrm{II})$ onto coir pith. Process Biochem 41:609-615

47. Dogan M, Alkan M, Turkyilmaz A, Ozdemir Y (2004) Kinetics and mechanism of removal of methylene blue by adsorption onto perlite. J Hazard Mater 109:141-148

48. Onyango MS, Kojima Y, Kumar A, Kuchar D (2006) Uptake of fluoride by $\mathrm{Al}^{3+}$ pre- treated low-silica synthetic zeolites: adsorption equilibrium and rate studies. Sep Sci Technol 41:683-704

49. Sinha S, Pandey K, Mohan D, Singh KP (2003) Removal of fluoride from aqueous solutions by Eichhornia crassipes biomass and its carbonized form. Ind Eng Chem Res 42:6911-6918

50. Mondal NK, Bhaumik R, Datta JK (2015) Removal of fluoride by aluminium impregnated coconut fiber from synthetic fluoride solution and natural water. Alexan Eng J. doi:10.1016/jaej.2015.08.006

51. Alagumuthu G, Rajan M (2010b) Equilibrium and kinetics of adsorption of fluoride onto zirconium impregnated cashew nut shell carbon. Chem Eng J 158:451-457

52. Nie Y, Hu C, Kong C (2012) Enhanced fluoride adsorption using Al (III) modified calcium hydroxyapatite. J Hazard Mater 233-234: 194-199

53. Xu X, Li Q, Cui H, Pang J (2011) Adsorption of fluoride from aqueous solution on magnesia-loaded fly ash cenospheres. Desalination 272:233-239

54. Wang XH, Song RH, Yang HC, Shi YJ, Dang GB, Yang S, Zhao Y, Sun XF, Wang SG (2013) Fluoride adsorption on carboxylated aerobic granules containing Ce(III). Bioresour Technol 127:106111

55. Kaygusuz H, UzasçS S, Erim FB (2015) Removal of fluoride from aqueous solution using aluminum alginate beads. Clean Soil Air Water 43(5):724-730

56. Ganvir V, Das K (2011) Removal of fluoride from drinking water using aluminum hydroxide coated rice husk ash. J Hazard Mater 185:1287-1294. doi:10.1016/j. jhazmat.2010.10.044

57. Alagumuthu G, Rajan M (2010a) Kinetic and equilibrium studies on fluoride removal by zirconium (IV) impregnated groundnut shell carbon. Hem Ind 64:295-304

58. Hernández-Montoya V, Ramírez-Montoya LA, Bonilla-Petriciolet A, MontesMoran M (2012) Optimizing the removal of fluoride from water using new carbons obtained by modification of nut shell with a calcium solution from egg shell. Biochem Eng J 62:1-7

59. Tchomgui-Kamga E, Alonzo V, Nanseu-Njiki C, Audebrand N, Ngameni E, Darchen A (2010) Preparation and characterization of charcoals that contain dispersed aluminum oxide as adsorbents for removal of fluoride from drinking water. Carbon 48(2):333-343 